University of Michigan Law School

University of Michigan Law School Scholarship Repository

Articles

Faculty Scholarship

1996

\title{
The Uniform Probate Code Extends Antilapse- Type Protection to Poorly Drafted Trusts
}

Lawrence W. Waggoner

University of Michigan Law School, waggoner@umich.edu

Available at: https://repository.law.umich.edu/articles/390

Follow this and additional works at: https://repository.law.umich.edu/articles

Part of the Estates and Trusts Commons, Legislation Commons, and the State and Local Government Law Commons

\section{Recommended Citation}

Waggoner, Lawrence W. "The Uniform Probate Code Extends Antilapse-Type Protection to Poorly Drafted Trusts." Mich. L. Rev. 94, no. 7 (1996): 2309-51.

This Correspondence is brought to you for free and open access by the Faculty Scholarship at University of Michigan Law School Scholarship Repository. It has been accepted for inclusion in Articles by an authorized administrator of University of Michigan Law School Scholarship Repository. For more information, please contact mlaw.repository@umich.edu. 


\title{
THE UNIFORM PROBATE CODE EXTENDS ANTILAPSE-TYPE PROTECTION TO POORLY DRAFTED TRUSTS
}

\author{
Lawrence W. Waggoner*
}

The Uniform Law Commission ${ }^{1}$ promulgated a revised version of Article II of the Uniform Probate Code (UPC or Code) in 1990, and approved a set of technical amendments in 1993. As Director of Research and Chief Reporter for the Joint Editorial Board for the Uniform Probate Code (Board) ${ }^{2}$ and reporter for the UPC Article II drafting committee, I was privileged to serve as the principal drafter of these provisions. UPC Article II deals with the substantive rules governing donative transfers - intestacy; spouse's elective share; execution, revocation, and revival of wills; rules of construction for wills and other donative transfers; and perpetuities. In all, UPC Article II contains eighty-five provisions, many of them brand new. The initial project took about four years to complete.

\section{SECTION 2-707}

In this article, I propose briefly to discuss one of the new provisions - section 2-707.3 I write this article because a prominent law teacher, Jesse Dukeminier, has published an article in this journal opposing this section. ${ }^{4}$ I address Professor Dukeminier's critique in Parts II and III. First, however, I discuss section 2-707 itself.

* Lewis M. Simes Professor of Law, University of Michigan; Director of Research, Joint Editorial Board for the Uniform Probate Code. - Ed. Copyright (c) 1996 by Lawrence W. Waggoner. The author wishes to thank Mary Louise Fellows, Edward C. Halbach, Jr., John H. Langbein, and Richard V. Wellman for helpful suggestions on an earlier draft and Nancy Nearing Go and Ariella Nasuti for valuable research assistance in preparing this article.

1. Short for National Conference of Commissioners on Uniform State Laws.

2. The Joint Editorial Board for the Uniform Probate Code (Board) is an organization jointly sponsored by the Uniform Law Commission, the American Bar Association, and the American College of Trust and Estate Counsel.

3. UNIF. PROB. CODE $\S 2-707$ (1993). For a more comprehensive treatment of $\S 2$ 707 and related provisions, see Edward C. Halbach, Jr. \& Lawrence W. Waggoner, The UPC's New Survivorship and Antilapse Provisions, 55 ALB. L. REv. 1091 (1992).

4. Jesse Dukeminier, The Uniform Probate Code Upends the Law of Remainders, $94 \mathrm{MICH}$. L. REv. 148 (1995). I sometimes refer to this article in the text as "Upending Remainders." 
Section 2-707 establishes a rule of construction for carrying out the donor's intention when a remainder beneficiary of a trust dies before the distribution date. ${ }^{5}$ The distribution date is the time when the remainder interest is to take effect in possession or enjoyment. ${ }^{6}$ As a practical matter, the distribution date usually occurs when the life tenant dies. This is when the trust is dissolved, and the corpus is distributed. If a remainder beneficiary dies before the distribution date, section 2-707 gives the corpus directly to the beneficiary's descendants who are then living. Section 2-707 replaces the rule at common law that sends the corpus back through the probate estate of the predeceased remainder beneficiary, a rule that can disinherit a descending line that has living members on the distribution date and can send a share down a descending line that previously died out.

Section 2-707 only applies to poorly drafted trusts. Well-drafted trusts, as described in more detail below, will not be affected by section 2-707 because they expressly provide for alternate takers if a remainder beneficiary dies before the distribution date. Section 2-707 treats an express provision in the trust document that designates alternate takers as controlling, and comes into operation only if the trust document fails to produce an alternative taker. ${ }^{7}$ By substituting the descendants of a remainder beneficiary of a poorly drafted trust who dies before the distribution date, section 2-707 carries out common intention - and the objective of most well-drafted trusts - by making sure that no descending line having a living member on the distribution date is disinherited, ${ }^{8}$ and that no share is sent down a descending line that previously died out.

5. A rule of construction is not a mandatory rule of law, but is a default rule designed to carry out presumed intent. A rule of construction yields to a finding of a contrary intent. See UNIF. PROB. CODE § 2-701 (1993); RESTATEMENT (THIRD) OP PROPERTY (Donative Transfers) $\S 11.3$ (a) cmt. a (Tentative Draft No. 1, 1995). This was approved by the American Law Institute at the 1995 Annual Meeting. 72 A.L.I. PRoc. 65 (1996).

6. UNIF. PROB. CODE § 2-707(a)(4) (1993).

7. See UNIF. PROB. CODE § 2-707(b)(4) (1993). For illustrations, see infra notes 17 and 89.

8. The Restatement of Property and the case law have long recognized a constructional preference for not disinheriting a line of descent. See RESTATEMENT (THIRD) OF PROPERTY (DONATIVE TRANSFERS) $\S 11.3(\mathrm{c})(3) \mathrm{cmt}$. j \& reporter's note 6 (Tentative Draft No. 1, 1995). This was approved by the American Law Institute at the 1995 Annual Meeting. 72 A.L.I. PROC. 65 (1996). See also RESTATEMENT OF PROPERTY $§ 243$ cmt. f (1940). 


\section{A. Well-Drafted Trusts}

The means employed in well-drafted trusts to preserve a share for each descending line having a living member on the distribution date, while not benefiting a descending line that previously died out, is to craft future interests in the form of multiple-generation class gifts with a survival requirement. Inasmuch as most future interests are to a class rather than to a named individual, ${ }^{9}$ it is usually wiser to craft the class gift as one to a multiple-generation class ("issue" or "descendants"), not as one to a single-generation class ("children," "grandchildren," "nieces and nephews," and so on)."

To illustrate how this technique serves to implement common intention, suppose a remainder to the "descendants" of the life tenant, $A$, with a survival requirement. If the life tenant, $A$, had two children, $X$ and $Y$, and $X$ predeceased the life tenant but $Y$ survived the life tenant, $Y$ would take it all if $X$ left no descendants surviving the life tenant, but $X$ 's descendants would divide $X$ 's half if $X$ left descendants surviving the life tenant. A single-generation class gift with a survival requirement can, in contrast, disinherit a descending line that has living members at the distribution date. If the remainder had been to $A$ 's "children" with a survival requirement, $Y$ would take the whole and $X$ 's estate would take nothing even if $X$ left descendants surviving the life tenant. A single-generation class gift without a survival requirement can send a share down a descending line that has no living members at the distribution date. If the remainder had been to $A$ 's "children" without a survival requirement, $Y$ would only take half and $X$ 's estate would take the other half even if $X$ left no descendants surviving the life tenant.

Because a well-drafted trust imposes a survival requirement, and thus does not create transmissible future interests, the trust must provide for the possibility that no remainder beneficiary will survive the distribution date. To assure that the corpus will always go directly to living beneficiaries when the trust is dissolved, a well-drafted trust provides for one or more alternative future interests, each of which is expressly

9. Future interests to named individuals are usually created when the donor does not anticipate that any additional persons in the same relationship will be bom or adopted, such as remainders to the donor's children or to the donor's brothers and sisters.

10. Equivalent language is sometimes used, such as "to divide the trust estate into equal shares, one for each child then living and one for the then-living descendants of each child then deceased."

11. See Edward C. Halbach, Jr., Future Interests: Express and Implied Conditions of Survival (pt. 2), 49 CAL. L. REV. 431, 469-70 (1961). 
contingent on the beneficiary surviving the distribution date. ${ }^{12}$ The last of the alternative future interests will be fail safe. If none of the preferred beneficiaries survives the distribution date, the trust will direct the corpus to a beneficiary or a set of beneficiaries certain to exist at the life tenant's death: one or more established charities, the persons who would be the donor's heirs were the donor to have died when the life tenant died, or the life tenant's heirs.

For clients who want to give a beneficiary flexibility to change who gets the property when the trust is dissolved, and allow a beneficiary to achieve certain tax objectives, capable estate planners would confer a power of appointment on the life tenant. The set of alternative remainder interests would still control the distribution of corpus, but only to the extent that the life tenant does not exercise the power.

\section{B. Transmissible Future Interests at Common Law}

A statutory reform is successful if it advances the law by giving a desirable result in a greater proportion of cases than the law it replaces. ${ }^{13}$ The law that section 2-707 replaces is the rule of construction favoring early vesting, a rule that produces transmissible future interests at common law. A corollary of the constructional preference for early vesting is the rule of construction that a remainder beneficiary need not survive the distribution date unless the terms of the document expressly require it. In the absence of an express requirement of survival, a remainder beneficiary has a transmissible future interest - a future interest that passes through the remainder beneficiary's probate estate if he or she predeceases the distribution date.

Estate planners have long been cautioned, and capable estate planners have long understood, that they should not create transmissible future interests. Indeed, one of the cardinal precepts of good estate planning is never to create a transmissible future interest. ${ }^{14}$ Transmissible

12. If the first remainder goes to the life tenant's then-living descendants, a common second choice is the closest collateral line of descent (the descendants of the life tenant's parents surviving the life tenant), followed perhaps by a third choice, the next collateral line of descent (the descendants of the life tenant's grandparents surviving the life tenant).

13. See Halbach \& Waggoner, supra note 3, at 1149.

14. See, e.g., 3 A. JAMES CASNER, Estate PlANNIng 1041 (4th ed. 1980) ("Normally it is unwise to create in an estate plan an interest in a class member (or in an individual to whom a future interest is given) that is not subject to a requirement of survival to the date set for beneficial enjoyment."); Edward C. Halbach, Jr., Future Interests: Express and Implied Conditions of Survival (pt. 1), 49 CAL. L. REv. 297, 307 (1961); Edward C. Halbach, Jr., Issues About Issue: Some Recurrent Class Gift Problems, 48 Mo. L. REv. 333, 366 (1983) [hereinafter Halbach, Issues About Issue] 
future interests can cause unnecessary estate taxes, can increase administrative and tracing costs, and can allow the property to be diverted outside the family or bloodline. ${ }^{15}$

UPC section 2-707 will never apply to a well-drafted trust. First of all, the section is wholly inapplicable to multiple-generation class gifts that are expressly contingent on survival of the distribution date. ${ }^{16} \mathrm{Sec}-$ ond, the section has no effect on a future interest if the beneficiary of an alternative future interest is entitled to take in possession or enjoyment. ${ }^{17}$ As noted, well-drafted trusts always provide for a fail-safe future interest of last resort. Consequently, UPC section 2-707 will have no effect at all on well-drafted trusts, and capable estate planners will not have to revise their forms. Section 2-707 only applies to poorly drafted trusts.

Even at common law, it is important to note, transmissible future interests only arise with respect to remainder interests to named individuals or to single-generation classes. In the case of remainder interests to multiple-generation classes, the common law does not give a predeceased beneficiary a transmissible future interest. Even when the language creating a future interest does not expressly require the beneficiaries to survive the distribution date, the common law subjects a future interest to a multiple-generation class to an implied requirement of survival. ${ }^{18}$ Implying a requirement of survival for multiple-generation class gifts supports section 2-707. Like section 2-707, it assures that no

(" $[\mathrm{I}] \mathrm{t}$ is virtually a matter of gospel among those skilled in estate planning and in the drafting of wills and trusts that remainder beneficiaries should be expressly required to survive until the time of distribution, in order to avoid a premature risk of property being diverted outside of the family or bloodlines, unwarranted administration and tracing difficulties, and unnecessary estate and inheritance taxation."); Halbach \& Waggoner, supra note 3, at 1134 ("Informed estate planners routinely impose express conditions of survival on the beneficiaries of future interests in trusts they draft."); Daniel M. Schuyler, Drafting, Tax, and Other Consequences of the Rule of Early Vesting, 46 ILL. L. REv. 407, 437 (1951) ("[T] he draftsman should never [create a transmissible future interest] to accomplish his purpose."):

15. See, e.g., Halbach, Issues About Issue, supra note 14, at 366; Edward H. Rabin, The Law Favors the Vesting of Estates. Why?, 65 CoLUM. L. REV. 467, 479-80 (1965); Schuyler, supra note 14, at 427-36; infra notes 54-60 and accompanying text.

16. See UNIF. PROB. CODE \& 2-707(b)(2) (1993).

17. See UNIF. PROB. CODE $§ 2-707$ (b)(4) (1993); supra text accompanying note 7; infra text accompanying note 69; infra note 89 . For example, suppose a trust to pay the income to $A$ for life, remainder to $B$ if $B$ survives $A$, but if not to the American Heart Association. If $B$ predeceases $A$, the American Heart Association takes the corpus even if $B$ leaves descendants who survive $A$.

18. See, e.g., Wright v. City of Tuscaloosa, 182 So. 72 (Ala. 1938); Weller v. Sokol, 318 A.2d 193 (Md. 1974); Old Colony Trust Co. v. Brown, 191 N.E. 358 (Mass. 1934); Kennard v. Kennard, 129 A. 725 (N.H. 1925), overruled on other grounds, 179 A. 414 (N.H. 1935). The Restatement (Second) of Property provides: 
descending line having a living member on the distribution date is disinherited, and no share is sent down a line that has died out by the distribution date.

When, with respect to a remainder to a named individual or to a single-generation class, a transmissible future interest arises at common law, it is usually due to a drafting deficiency. A classic and recurrent drafting deficiency is to write a condition of survival as a condition subsequent rather than as a condition precedent. In In re Krooss, ${ }^{19}$ the testator's will devised his residuary estate to his wife Eliese for life, then to his two children, John and Florence. The provision producing a transmissible future interest was:

In the event that either of my children aforesaid should die prior to the death of my beloved wife, Eliese Krooss, leaving descendants, then it is my wish and I so direct that such descendants shall take the share their parent would have taken if then living, share and share alike, to and for their own use absolutely and forever. ${ }^{20}$

John survived his mother, but Florence predeceased her, without descendants but with a surviving husband. The court held that Florence had a transmissible future interest regarding half of her father's residuary estate, which passed under her residuary clause in trust for her husband. Applying the preference for early vesting, the court said:

[D]ivestiture of the remainder estates depended upon the happening of two plainly expressed and stipulated conditions: (1) the child, Florence or John, must die before the life beneficiary, and (2) the child so dying must leave descendants. Only if both of those conditions came to pass was the remainder - by apt and unequivocal language already vested in Florence and John - to be divested and bestowed instead upon the descendants of him or her who might have died.21

Because the gift over specified Florence's descendants, it appears doubtful that the testator understood that he was giving Florence a transmissible future interest if she predeceased her mother without leaving descendants. More likely, he thought that John or his descendants would take Florence's share, if he thought about it at all. It also appears doubtful that Florence or her attorney understood that she owned a

If a gift is made to a class described as the "issue" or "descendants" of a designated person, or by a similar multigenerational class gift term, in the absence of additional language or circumstances that indicate otherwise, ... . [a] class member must survive to the date of distribution in order to share in the gift ....

Restatement (SECOND) OF PROPERTY (DONATIVE TRANSFERS) § 28.2 (1987).

19. 99 N.E.2d 222 (N.Y. 1951).

20. 99 N.E.2d at 223 (internal quotation marks omitted).

21. 99 N.E.2d at 224. 
transmissible future interest that was contingent on her dying before her mother without descendants, or that she deliberately devised it under her residuary clause. The use of a condition subsequent disguises the meaning that the courts, applying the early vesting rule, attribute to such language. Had the testator's lawyer drafted the condition in the form of a condition precedent, the testator would have understood the meaning of what he was asked to sign, and one doubts that he would have signed it. Had the condition been cast in the form of a condition precedent, it would have read: "to Florence if she either survives her mother or predeceases her mother without leaving any descendants; if she predeceases her mother leaving descendants, then to such descendants." Had section 2-707 applied to the Krooss case, ${ }^{22}$ the testator's son John would have taken the whole directly upon Eliese's death; Florence's husband would not have benefited from the addition of that half share to the corpus of the residuary trust created in Florence's will. ${ }^{23}$

Another classic and recurrent drafting deficiency leading to a transmissible future interest at common law is writing a condition of survival into the first future interest but neglecting to write it into one or more alternative future interests in favor of identified individuals or single-generation classes. A simplified illustration of this type of drafting error is "income to $A$ for life, remainder to $B$ if $B$ survives $A$, but if not to $B$ 's children." 24 The alternative future interest to $B$ 's children is contingent on $B$ predeceasing $A$, but it is not expressly contingent on $B$ 's children surviving $A$. Failure to write a condition of survival into the alternative future interest to $B$ 's children can cause litigation if $B$ and one or more of $B$ 's children predecease $A$. The common law response to this situation is neither monolithic nor consistent with the well-drafted trust.

The majority rule holds that the alternative future interest is not conditioned on survival, thus giving the beneficiaries of the alternative future interest a transmissible future interest even if the deceased beneficiaries die without issue. ${ }^{25}$ This is what happened in In re Bomberger's Estate. ${ }^{26}$ By applying the majority rule, the court sent shares of the trust

22. Although § 2-707 would not have applied to the devise in Krooss because it was not in trust, the devise illustrates the type of provisions often found in poorly drafted trusts.

23. Remember that Florence's husband would not have lost out entirely. Florence's own residuary estate would still have gone into her residuary trust for him.

24. See Halbach, supra note 11 , at $469-70$.

25. See 5 AM. L. Prop. § 21.25 (A. James Casner ed., 1952); 2 LewIS M. Simes \& ALLAN F. SMITH, THE LAW OF FUTURE INTERESTS $\$ \S 594,655$ (2d ed. 1956).

26. 32 A.2d 729 (Pa. 1943). 
down descending lines that had died out by the distribution date. The testator's will devised $\$ 50,000$ in trust, income to his niece, Lilly Aughinbaugh, for life, corpus on Lilly's death to her children. The will continued:

Should [niece Lilly] die without leaving a child or children, I order and direct that the bequest ... shall be equally divided among my nephews and nieces ... then living, the child or children of nieces who may be deceased to have the share their mother would have been entitled to if living $\ldots .{ }^{27}$

As the facts turned out, Lilly died childless, never having had any children, and all of the testator's nieces and nephews predeceased Lilly. Ada, one of the predeceased nieces, had eight children: seven of them survived Lilly, but one, John, predeceased Lilly. John also predeceased his mother, Ada. Annie, the other predeceased niece, had one child, Rachel, who predeceased Lilly. John and Rachel apparently died childless, although the court does not specifically so state.

The dispute arose between Ada's seven living children and the executors of John's and Rachel's estates. If the third remainder, the one to the children of nieces who predeceased Lilly, was contingent on survival of Lilly, Ada's seven children would split the corpus, each receiving a one-seventh share. The court, however, held that the remainder was not contingent on surviving Lilly. The result: Ada's seven living children and John's estate split half of the corpus, one sixteenth each, and Rachel's estate took a full one-half share. As in Krooss, the testator probably did not understand that his disposition created transmissible future interests in John and Rachel that were contingent on Lilly dying without children and on their own mothers predeceasing Lilly. It also appears doubtful that John or Rachel understood that he or she owned such a transmissible future interest.

The minority rule holds that the alternative future interest is conditioned on survival even if the deceased beneficiaries left descendants surviving the distribution date. ${ }^{28}$ This is what happened in Lawson $v$. Lawson, ${ }^{29}$ a case in which the court applied the minority rule and disinherited two lines of descent with living members at the distribution date. The testator's will devised land to his daughter Opal Lawson Long for her life, and at her death "to her children, if any, in fee simple; if

27. 32 A.2d at 730 (last alteration in original) (internal quotation marks omitted).

28. See 5 AM. L. PROP., supra note $25, \S 21.25 ; 2$ SiMES \& SMITH, supra note 25 , $\S \S 594,655$. For a recent case applying the minority rule, see Rushing v. Mann, 910 S.W.2d 672 (Ark. 1995).

29. 148 S.E.2d 546 (N.C. 1966). 
none, to [Opal's] whole brothers and sisters." 30 The will, in effect, created a life estate in Opal, followed by alternative contingent remainders: first, to Opal's children, if any; and second, to Opal's whole brothers and sisters, contingent on Opal not leaving any children.

As the facts turned out, Opal died childless, and four of her six whole brothers and sisters survived her. The other two brothers survived the testator but predeceased Opal. One of the predeceased brothers left a child, William, who survived Opal and claimed a one-sixth share through his father's estate. The other predeceased brother left four children, Leo, Kenneth, Bonnie, and Barbara, who survived Opal and collectively claimed a one-sixth share through their father's estate. The court held that the second alternative remainder was contingent on survival of Opal, and thus that the corpus went exclusively to the four surviving brothers and sisters.

To summarize, neither Bomberger nor Lawson gave a result that is consistent with a well-drafted trust. Section 2-707 cures the failure of the common law in both cases. Were section 2-707 applicable, ${ }^{31}$ none of the corpus in Bomberger would have gone down descending lines that had died out, whereas in Lawson, the two lines that still had living members would not have been disinherited.

A further complexity associated with these problems arises when a remainder interest is subject to an express requirement of survival, but the language is ambiguous because it does not clearly specify the time of survival. The predominant constructional preference at common law, as set forth in section 251 of the original Restatement of Property, is that ambiguous language of survival "tends to" refer to the distribution date rather than to some other time, such as the testator's death. ${ }^{32}$ This constructional preference makes sense when applied to a multiple-generation class gift. But, when applied to a single-generation class gift; this constructional preference can disinherit a descending line.

A recent case, In re Gustafson, ${ }^{33}$ shows how this rule of construction can work mischief when applied to a single-generation class gift. Carl Gustafson died leaving a will that devised about half of his estate in two trusts, the income from one to be paid to his wife Elsie for life. Upon Elsie's death, the corpus was to be distributed:

(a) One-half to my brother, E. Leonard Gustafson.

30. 148 S.E.2d at 547 (internal quotation marks omitted).

31. Although § 2-707 would not have applied to the devise in Lawson because it was not in trust, the devise illustrates the type of provisions often found in poorly drafted trusts.

32. See Restatement of Property $\S 251$ (1940).

33. 547 N.E.2d 1152 (N.Y. 1989). 
(b) One-half to my brother, Roy L. Gustafson.

(c) If a brother predeceases Elsie Warren Gustafson, then his share of this Trust shall be paid over to his surviving child or children, share and share alike.

(d) If one of my brothers shall predecease Elsie Warren Gustafson, without issue surviving, then his part of this Trust shall be paid over to his surviving brother. ${ }^{34}$

Roy survived Elsie and took his half. Leonard predeceased Elsie, leaving a daughter Jacqueline and a son Daniel surviving him. Jacqueline survived Elsie as well, but Daniel predeceased Elsie, leaving a widow and children who survived Elsie. Relying on Restatement of Property section 251, the court held that the condition of survival on the interest of Leonard's children related to Elsie's death; consequently, Jacqueline took all of Leonard's half, and Daniel's widow and children took nothing. Under UPC section 2-707, however, Jacqueline would have only taken half of Leonard's half. Leonard's grandchildren (Daniel's children) would have taken the other half of Leonard's half.

Coexisting with the above case law, however, is a lesser-known line of common law authority that approaches the problem from a different angle. In Krooss, Bomberger, and Lawson, the question was whether a future interest to a named individual or to a single-generation class was conditioned on survival of the distribution date. In Gustafson, the question was whether the ambiguous language of survival referred to the distribution date or some other time. Under this alternative line of authority, the courts have asked a different question: whether to "construe" a remainder interest to a single-generation class (and occasionally to named individuals) to exclude a remainder beneficiary who predeceases the distribution date (without regard to whether there was an express requirement of survival) but to include that remainder beneficiary's children or more remote descendants who survive the distribution date. ${ }^{35}$ Although courts usually say that answering this question in the

34. 547 N.E.2d at 1153 (internal quotation marks omitted) (emphasis added).

35. In Gustafson, Judge Hancock, dissenting, sought to construe the word "children" to mean "issue," in order to divide Leonard's half equally between Jacqueline's and Daniel's children. "In my view," he said, "construing 'children' narrowly here and, thereby, disinheriting the lineal descendants of one of the testator's brothers is unwarranted and represents a distinct - and unfortunate - extension of the 'unmistakable intent' rule." 547 N.E.2d at 1155 (Hancock, J., dissenting in part). Judge Hancock's argument was strengthened by the fact that the dispositive language used "children" and "issue" interchangeably. See Restatement (SECOND) OF PROPERTY (DONATIVE TRANSFERS) $\S 25.1 \mathrm{cmt}$. j \& reporter's note 5c, at 23-24 (1987) (citing cases) (use of "children" and "issue" interchangeably can lead to construing "children" to mean "issue"); RESTATEMENT OF PROPERTY $\$ 285(2)$ (c) \& cmt. j (1940); Security Trust \& Safe Deposit Co. v. Lockwood, 118 A. 225 (Del. Ch. 1922); Tucker v. Tucker, 82 S.W.2d 458 (Ky. 
affirmative requires an affirmative showing that the settlor used the single-generation class-gift term in a nonliteral and expanded sense, ${ }^{36}$ there are cases that have found such an intent on the basis of slender evidence, presuming such an intent in all but name - as section 2-707 does directly.

In Cox v. Forristall, ${ }^{37}$ for example, a case containing an express requirement of survival, ${ }^{38}$ the testator's will (in simplified form) ${ }^{39}$ devised his farm to his daughter Alice for life, and at Alice's death to his other children (naming them). The will continued:

In the event of death of [any] of my children above named prior to [Alice's death], the share of such child or children so dying shall descend to, become and be the property of the then living issue of their body, and in the event of their dying without issue, the share of such child or children so dying shall descend to, become and be the property of my children then living, share and share alike. ${ }^{40}$

1935); In re Estate of McKim, 192 N.Y.S.2d 1011 (Sur. Ct. 1959); Edmundson v. Leigh, 126 S.E. 497 (N.C. 1925); Rogerson v. Wheeling Dollar Sav. \& Trust Co., 222 S.E.2d 816 (W. Va. 1976). But see RESTATEMENT (SECOND) OF PROPERTY (DONATIVE TRANSFERS) $\S 25.9 \mathrm{cmt}$. d (1987) (using "children" and "issue" interchangeably can lead to construing "issue" to mean "children"). Judge Hancock's argument that "children" meant issue would have been further strengthened had the language said "children, per stirpes" rather than "children, share and share alike." See id. \$ $25.1 \mathrm{cmt}$. i, illus. 14; Trust Co. Bank v. Heyward, 242 S.E.2d 257 (Ga. 1978); In re Blodgett's Will, 294 N.Y.S. 358, 366-67 (App. Div. 1937) (construing "children ... per stirpes and not per capita" to include issue of a deceased child); In re Clark's Estate, 59 A.2d 109 (Pa. 1948); In re Grubb's Estate, 106 A. 787 (Pa. 1919).

The dissenting judges in the earlier case of In re Welles' Will, 173 N.E.2d 876 (N.Y. 1961), had failed by one vote in their effort to avoid a result comparable to that of Gustafson by construing "then surviving grandchildren" as including great-grandchildren. The dissenters expressed grave doubt that the testator wished two of his five branches of descendants to be excluded simply because of an unusual order of deaths.

36. See, e.g., RESTATEMENT (SECOND) OF PROPERTY (DONATIVE TRANSFERS) $\S 25.1$ cmts. g-j (1987). Cases finding such an intent are collected in Sara L. Johnson, Annotation, Word "child" or "children" in will as including grandchild or grandchildren, 30 A.L.R.4th 319 (1984). Some of the cases cited in this annotation are inapposite to the issues under discussion because the beneficiary of the future interest predeceased the testator, making it impossible to hold that the beneficiary received a transmissible interest. See, e.g., Spencer v. Title Guarantee Loan \& Trust Co., 132 So. 32 (Ala. 1931); Wilson v. Rand, 110 So. 3 (Ala. 1926); In re Estate of Schedel, 15 P. 297 (Cal. 1887); Bowker v. Bowker, 19 N.E. 213 (Mass. 1889).

37. 640 P.2d 878 (Kan. Ct. App. 1982).

38. Cox and the cases cited infra note 41 provide common law support for the position, explicitly adopted in $\$ 2-707$, that a condition of survival does not indicate an intent contrary to substituting descendants for deceased beneficiaries. See UNIF. PROB. CODE \& 2-707(b)(3) (1993). Ignoring this line of authority, Professor Dukeminier belittles the UPC position on this point. See Dukeminier, supra note 4, at 153-54.

39. The actual disposition was more complicated, but in ways not relevant to the point made in the text.

40. Cox, 640 P.2d at 881 (emphasis added). 
The testator was survived by eleven children, including Alice. Only one of the eleven, Delilah, survived Alice. Five died during Alice's lifetime without issue and five died during Alice's lifetime with issue (who survived Alice). The question here was whether the shares of the five who died without issue went only to Delilah or whether it went to Delilah and the issue of the five who predeceased Alice with issue. Construing the alternative future interest to "my children then living" to include the issue of the five deceased children despite the condition of survival, ${ }^{41}$ the court rejected Delilah's argument that she should get all five shares, saying that her argument would "give[] the last to die the biggest shares." 42 The court cited an earlier decision of the Kansas Supreme Court that said that "[i]f there appears to be a doubt or uncertainty as to the grantor's intention in using the word 'children' there is a reasonable presumption against disinheritance of a grandchild whose parent is dead." 43 Had section 2-707 applied, ${ }^{44}$ it would have reached the same result.

Another case within this alternative line of authority is Edwards $v$. Bender. ${ }^{45}$ Unlike the dispositive language in Cox, the dispositive language in Edwards did not contain an express requirement of survival. The testator's will devised a tract of land to his daughter Nancy for life, remainder to Nancy's "children," without an express requirement of survival. Nancy had five children. Four of the five survived her, but one predeceased her, leaving a child, Eula, who survived her. Rather than apply the early vesting rule, which would have given the predeceased

41. For other cases reaching the same result despite a condition of survival, see, for example, In re Estate of Englis, 255 A.2d 242, 244, 247 (N.J. 1969) (in order to avoid producing an "unnatural result which we believe was never intended by the testator," court construed "then living children of any of my said five children" to include the children's grandchildren); In re Paton, 18 N.E. 625 (N.Y. 1888); Pfender v. Depew, 121 N.Y.S. 285 (App. Div. 1910); In re Meyn's Will, 81 N.Y.S.2d 129 (Sur. Ct. 1948); In re Stecher's Will, 73 N.Y.S.2d 595 (Sur. Ct. 1947); In re Clark's Estate, 59 A.2d 109 (Pa. 1948); Douglas v. James, 28 A. 319 (Vt. 1893); Rogerson v. Wheeling Dollar Sav. \& Trust Co., 222 S.E.2d 816 (W. Va. 1976); Security Natl. Bank \& Trust Co. v. Willim, 158 S.E.2d 715 (W. Va. 1968). In the preceding cases, one or more but not all of the remainder beneficiaries predeceased the distribution date. The same result has been reached where all of the remainder beneficiaries predeceased the distribution date. See, e.g., In re Craig's Estate, 148 P.2d 100 (Cal. Dist. Ct. App. 1944); Hodge v. Lovell's Trustee, 90 S.W.2d 683 (Ky. 1936); In re Court's Estate, 91 N.Y.S.2d 881 (Sur. Ct. 1949); In re Harrison's Will, 73 N.Y.S.2d 162 (Sur. Ct. 1947).

42. Cox, 640 P.2d at 884 .

43. In re Works' Estate, 213 P.2d 998, 1001 (Kan. 1950) (quoting Bennett v. Humphreys, 155 P.2d 431, 432 (Kan. 1945)), cited in Cox, 640 P.2d at 884-85.

44. Although § 2-707 would not have applied to the devise in Cox because it was not in trust, the devise illustrates the type of provisions often found in poorly drafted trusts.

45. 25 So. 1010 (Ala. 1899). 
child a transmissible future interest, the court held that the word "children" "may be extended to include grandchildren, when such intent appears from the whole instrument, or where otherwise the devise would fail." 46 Although the devise would not otherwise fail (because four of Nancy's five children survived her), the court found it "evident" that the testator's intention, "though not expressly stated," was that "the issue of such of her children as might die before [the life tenant] should take the share which such deceased child would have taken." ${ }^{47}$ Were section 2-707 applicable, ${ }^{48}$ it would have reached the same result.

In effect, the Cox-Edwards line of authority, like section 2-707, presumptively converts a remainder to a single-generation class into a multiple-generation class gift with a survival requirement.

\section{Momentum for a Statute like Section 2-707}

Momentum has long been building for a statute like section 2-707. Transmissible future interests, which result from the constructional preference for early vesting, have been embattled in the scholarly literature for decades. Although the original basis for the rule of early vesting is obscure, ${ }^{49}$ the desire to avoid the now-defunct rule of destructibility of

46. 25 So. at 1012. For other cases in which the court, rather than giving the deceased beneficiary a transmissible future interest, construed the word "children" to include issue of deceased children, see, for example, Works, 213 P.2d at 1001; Haas v. Canton of Bern, 54 A.2d 213 (N.J. Ch. 1947); Farmers' Trust Co. v. Borden, 89 A. 985 (N.J. Ch. 1914); In re Estate of McNeil, 238 N.Y.S.2d 389 (App. Div. 1963); In re Blodgett's Will, 294 N.Y.S. 358 (App. Div. 1937); In re Niegsch's Will, 294 N.Y.S.2d 583 (Sur. Ct. 1968); In re Wait's Estate, 42 N.Y.S.2d 735, 738 (Sur. Ct. 1943) ("Where the will fails to denote whether grandchildren were intended to be included in the term 'children', the presumption that the designation was used in its primary sense should bow to the presumption against disinheritance. . . . No grandchild is here otherwise provided for, the clause in dispute disposes of the entire estate, and the will discloses no apparent intention to exclude the issue of a deceased child from among those who are to share in his estate. The Court accordingly determines that the term 'children' as employed herein includes the grandchild of decedent." (citation omitted)); In re Davis' Estate, 214 N.Y.S. 142 (Sur. Ct. 1925); In re Albertson's Estate, 198 A. 152 (Pa. 1938) ("children" and "issue" used interchangeably, but court relied on other factors); In re Campbell's Estate, 51 A. 1099 (Pa. 1902); David v. Mitchell, 178 S.W.2d 889 (Tenn. Ct. App. 1943); Davis Trust Co. v. Elkins, 175 S.E. 611, 614 (W. Va. 1934) ("[I]t is an accepted rule of construction in the interpretation of wills that a presumption exists against the testator's disinheriting direct descendants ...."). See also cases cited infra note 118 .

47. Edwards, 25 So. at 1012. The court based this conclusion on the fact that the will contained a gift over in case Nancy died without issue. Nancy, of course, did not die without issue; she was survived by four of her five children.

48. Although $\S 2-707$ would not have applied to the devise in Edwards because it was not in trust, the devise illustrates the type of provisions often found in poorly drafted trusts.

49. See Rabin, supra note 15 , at 480 n.87. 
contingent remainders ${ }^{50}$ certainly played a large part, ${ }^{51}$ as did the once overly harsh but now widely liberalized rule against perpetuities..$^{52}$ Like so many rules in this area, the original basis for the rule has disappeared, but the rule itself persists. As previously noted, estate planners have long been cautioned, and capable estate planners have long understood, that they should not create transmissible future interests. Transmissible future interests can cause unnecessary estate taxes, can increase administrative and tracing costs, and can allow the property to be diverted outside the family or bloodline. ${ }^{53}$

In a masterful article published in 1951, Daniel Schuyler, a law professor and a practicing estate-planning attorney of the first rank, wrote: "Sometimes the rule of early vesting has the effect of defeating what any sensible person would assume to be the intention of a testator."54 Professor Rabin explained why: "[Passing] property to a dead person's estate .... is undesirable because it raises the possibility that persons whom the testator had no intention of benefiting will become

50. In most states, the destructibility rule is abolished by statute. See SIMES \& SMITH, supra note $25, \S 207$. Even where not abolished by statute, the destructibility rule would probably not be recognized today. See Abo Petroleum Corp. v. Amstutz, 600 P.2d 278 (N.M. 1979) (refusing to apply the destructibility rule); RESTATEMENT OF PROPERTY § 240 (1936) (propounding "antidestructibility rule").

51. See RESTATEMENT OF PROPERTY $\$ 243 \mathrm{cmt}$ i (1940); Schuyler, supra note 14, at $408-18$.

52. The Uniform Probate Code contains the Uniform Statutory Rule Against Perpetuities, which adopts the wait-and-see-plus-deferred-reformation method of perpetuity reform. See UNIF. PROB. CODE $\S \S 2-901$ to 2-906 (1993).

53. On unnecessary death taxation, see, for example, I.R.C. $\$ 2033$ (1994); Treas. Reg. $\S 20.2033-1$ (a)(1) (as amended in 1965); Treas. Reg. $\$ 20.2033-1$ (a) (as amended in 1963); Rev. Rul. 76-472, 1976-2 C.B. 264, 264 ("[F]uture interests in property that a decedent owns at death are taxed just as possessory interests. Thus, the value of a vested remainder interest is includible in the value of the remainderman's gross estate under section 2033 of the Code even though the remainderman dies before obtaining possession of the property."); see also Coddington v. Stone, 9 S.E.2d 420 (N.C. 1940) (concluding that testator's son had a transmissible future interest, which passed by intestacy on the son's death prior to the distribution date, thus subjecting the property to state inheritance taxes and to federal estate taxes). On difficulties of tracing transmissible future interests that have been omitted from inventories and decrees, see, for example, In re Latimer's Will, 63 N.W.2d 65, 72 (Wis. 1954). On potential diversion of the property outside the family or bloodline, see infra notes 54-60 and accompanying text.

54. Schuyler, supra note 14 , at 427 . Schuyler added:

[T] here are instances when the rule of early vesting positively defeats intention

- by casting property to strangers, by making property available to creditors, and by subjecting it to successive death taxes. A careful balancing of the reasons for and against the rule of early vesting indicates that social changes have robbed it of its once great virility. Its repudiation could well be followed by the adoption of the rule of construction ... that a gift distributable in the future is prima facie contingent on survivorship.

Id. at 441 . 
his de facto beneficiaries." 55 Examples abound. One is Peadro v. Peadro, ${ }^{56}$ where "[t]he effect [of allowing the future interest to be transmissible] was to invest the second wife of the husband of a niece of the testator - a person wholly unrelated to the testator even by marriage - with an undisclosed portion of the fee." 57 Another is De Korwin v. First National Bank," where "the [transmissible future interest ended up in the hands of] the second wife of a son-in-law of the testator again an utter stranger." 59 Judicial recognition of the fact that "[e]arly vesting frequently frustrates intentions by casting property to strangers" led the Illinois court to rule that "early vesting of remainders should no longer be followed in this State without question." 60

There is another side to the issue, however. Although a transmissible future interest might end up in the hands of someone outside the family or bloodline, it might not. In modern times, scholars have argued that this possibility is the only reason for retaining the rule. Rabin wrote that the principal advantage of the rule of early vesting is that it "tends to prevent unintended disinheritance of the issue of a deceased remainderman. . . . [T]oday this is the rule's principal raison d'etre and no doubt explains why the preference for vesting is particularly strong where the remainderman is a descendant of the testator." 61 The Restatement (Second) of Property recently stated that the only modern justification for the rule of early vesting is "that it enables the deceased class member to pass his share to his issue, thereby keeping the benefits of the gift equal among the descendant lines." 62 This is what I call the

55. Rabin, supra note 15 , at 479 .

56. 81 N.E.2d 192 (IIl. 1948).

57. Schuyler, supra note 14 , at 428 .

58. 179 F.2d 347 (7th Cir. 1949), cert. denied, 339 U.S. 982 (1950).

59. Schuyler, supra note 14 , at 429.

60. Harris Trust \& Sav. Bank v. Beach, 513 N.E.2d 833, 838-39 (Ill. 1983). Although the Restatement of Property included constructional preferences for early vesting and for early indefeasibility, see RESTATEMENT OF PROPERTY $\S 243 \mathrm{cmts}$. i-j (1940), both constructional preferences were dropped from the newer Restatement (Third) of Property (Donative Transfers). See RESTATEMENT (THIRD) OF PROPERTY (DONATIVE TRANSFERS) $\S 11.3$ (Tentative Draft No. 1, 1995). This was approved by the American Law Institute at the 1995 Annual Meeting. 72 A.L.I. PROC. 65 (1996).

61. Rabin, supra note 15 , at $483-84$.

62. Restatement (SECOND) OF Property (DONATIVE TRANSFers) $\S 27.3 \mathrm{cmt}$. a (1987). Comment e also notes that

The substitution of the issue of a class member who dies after the dispositive instrument takes effect and before such class member's share is distributable will cause the various lineal lines to be treated equally. This equal treatment of lineal lines can be accomplished by the deceased class member's will if there is no substitute gift to issue. The substitute gift to issue route, however, avoids passing the gift to the deceased class member's issue through the deceased class member's estate. Because of the undesirability of having the gift pass through the deceased 
"trickle-down theory," which is that the future interest might trickle down through the deceased remainder beneficiary's estate and, when the trust is dissolved at some later time, the property itself might end up in the hands of his or her descendants. Of course, as noted above, it might not. Indeed, the remainder beneficiary might die without issue. The remainder beneficiary might die intestate, in which case there might be multiple heirs, one or more of whom also predecease the distribution date. The property can easily end up in the hands of complete strangers.

Consequently, the trickle-down theory is a hit-or-miss mechanism for protecting the predeceased remainder beneficiary's descendants from disinheritance. A more direct and efficient means of protecting these descendants is by legislation extending antilapse-type protection to future interests. Long before section 2-707 was promulgated, commentators had favored such a statute. Rabin wrote:

It might well be preferable to protect the issue of deceased remainderman by legislation, rather than by the rule favoring vesting. An amendment to the anti-lapse statutes to protect the issue of persons who died after the decedent would eliminate the need for strained attempts to avoid implied requirements of survival. ${ }^{63}$

Similarly, the Restatement (Second) of Property stated that "it would be a better overall result to [substitute a class member's surviving descendants] for the deceased class member and avoid involvement of the class member's share in his or her estate." 64

This is what section 2-707 does. It establishes a rule of construction, which yields if there is a finding of a contrary intention, 65 that substitutes a remainder beneficiary's descendants who survive the distribution date for a remainder beneficiary who predeceases the distribution date. ${ }^{66}$ As recommended in the Restatement (Second), ${ }^{67}$ in the literature,

member's estate and because the provision for substitution of issue is a sufficient indication of the donor's intent that he did not wish such a result, it should be presumed, in the absence of contrary indication, that the donor who provides for substitution of issue intends that the share of the other class members be enlarged if a class member fails to survive to the date of distribution and leaves no issue who so survive.

Id. $\S 27.3 \mathrm{cmt}$. e (citation omitted).

63. Rabin, supra note 15 , at 487 .

64. Restatement (SECOND) OF PROPERTY (DONATIVE TRANSFERS) $\S 27.3 \mathrm{cmt} . \mathrm{b}$ (1987). The Restatement, written before UPC $\S 2-707$ was promulgated, also noted with approval the non-UPC statutory law in a few states that substitutes descendants of predeceased remainder beneficiaries and added that "[t]he policy of these statutes commends itself to decisional law." Id. $\S 27.3 \mathrm{cmt}$; see also Halbach, Issues About Issue, supra note 14, at $367 \mathrm{n} .142$ (describing this statutory law with approval).

65. See UNIF. PROB. CODE § 2-701 (1993).

66. See UNIF. PROB. CODE § 2-707(b)(1)-(2) (1993).

67. See supra note 64 . 
and by analogy to the well-drafted trust, descendants were chosen as the appropriate substitute takers. ${ }^{68}$ To prevent the statute from being intentdefeating, the substitution of descendants only applies if the trust document fails to create an alternative future interest that is entitled to take effect in possession or enjoyment. ${ }^{69}$

\section{DUKEMINIER Dissents, Supporting TRANSMissible Future INTERESTS}

Revised Article II has naturally sparked a flurry of law review articles by legal academics. It was the subject of a conference in 1992 at the Albany Law School. The conference was followed by publication of a symposium issue of the Albany Law Review collecting articles by the participants and some nonparticipants. ${ }^{70}$ The symposium articles were both constructive and valuable. In our introduction to the symposium issue, John Langbein and I wrote:

We are particularly impressed and gratified that there is no serious disagreement in these many scholarly articles with the grand themes of the new UPC article II. It is hard to find a trace of dissent in the symposium papers concerning the major policy premises of the legislation unifying the law of probate and nonprobate transfers, overcoming intentdefeating formalities, and achieving greater equity in spousal property relations. Our symposium authors do, however, remind us that in translating large policy concepts into highly specific legislative prescriptions, a host of detailed choices arise, and these choices entail important practical consequences. Many of these choices are close substitutes; there are often good arguments for each. We have tried in this paper, as in the drafting of UPC article II itself, to explain the choices that were made, while conceding that complete consensus on matters of statutory detail cannot be achieved. We take away from this valuable symposium a deep sense of satisfaction that the new UPC article II has attracted so much support from a group of specialist authors whose job is to be critical and probing. We reiterate that the task of revision is never ending, and that as experience shows the need for reforming the reforms, scholars and prac-

68. See also sources cited supra note 8 (describing the long-standing constructional preference for not disinheriting a line of descent). Substituting descendants is also the most conservative set of substitute takers. Although some settlors might agree with substituting a broader set of substitute takers, nearly all settlors would agree with substituting the remainder beneficiary's descendants. See also infra text accompanying note 133 (describing preference of leading practitioners for substituting descendants); infra note 136 and accompanying text (same).

69. See UNIF. PROB. CODE § 2-707(b)(4) (1993). See supra note 17 and infra note 89 for illustrations of this feature of the Code.

70. Symposium on the Uniform Probate Code: Reflections on Recent Revisions, 55 ALB. L. REV. 869 (1992). 
titioners will find a warm welcome when they bring needed repairs to the attention of the [Joint Editorial Board]..$^{71}$

Some of the ideas in the symposium articles found their way into the 1993 technical amendments to the Code..$^{72}$

None of the articles in the symposium and only a few articles outside the symposium have disagreed with the objectives of the UPC revisions. In The Uniform Probate Code Upends the Law of Remainders, ${ }^{73}$ however, Jesse Dukeminier, professor emeritus at the UCLA School of Law, writes in opposition to the objectives of UPC section 2707 because it presumptively does away with transmissible future interests in trust. As noted in Part I, the thrust of section 2-707 is to make sure that no descending line having a living member on the distribution date is disinherited, and that no share is sent down a line that has died out by the distribution date. In Upending Remainders, Professor Dukeminier, without mentioning any of the authorities discussed in Part I reproving transmissible future interests and supporting a legislative response like section $2-707,{ }^{74}$ describes this idea variously as "revolutionary,"75 based "purely on [the drafters'] own speculation,"76 bereft of empirical evidence showing "that the common law has read people wrong for centuries," 77 "retrogressive,"

71. John H. Langbein \& Lawrence W. Waggoner, Reforming the Law of Gratuitous Transfers: The New Uniform Probate Code, 55 AlB. L. REv. 871,890 (1992).

72. For example, the article by Professor Ira Mark Bloom led to a revision of $\S 2$ 209(a). See Ira Mark Bloom, The Treatment of Trust and Other Partial Interests of the Surviving Spouse Under the Redesigned Elective-Share System: Some Concerns and Suggestions, 55 ALB. L. REv. 941, 975-77 (1992). The article by Professor Sheldon F. Kurtz led to the addition of $\S 2-707(\mathrm{e})$. See Sheldon F. Kurtz, Powers of Appointment Under the 1990 Uniform Probate Code: What Was Done - What Remains To Be Done, 55 ALB. L. REV. 1151, 1199-1201 (1992).

73. Dukeminier, supra note 4.

74. See supra notes 49-69 and accompanying text. Dukeminier does acknowledge that "a number of academic commentators opposed the common law presumption of vesting," but attributes this only to "the potential estate taxation of a remainder at a remainderman's death," a disadvantage that he says "was neutralized, however, with the enactment of the federal generation-skipping transfer (GST) tax in 1986." Dukeminier, supra note 4, at 162-63 (discussing I.R.C. $\$ \$ 2601-2663$ (1994)). Dukeminier does not mention that these commentators were mainly concerned with the possibility of the property passing outside of the family or bloodline.

75. Dukeminier, supra note 4, at 150.

76. Id.

77. Id. Dukeminier is not always impressed by statistical evidence. In an earlier article attacking another uniform act (the Uniform Statutory Rule Against Perpetuities or USRAP), Dukeminier labeled the 90-year wait-and-see perpetuities period as a "clone" of the "dozen-healthy-babies" ploy, a device that is unused in actual practice. See Jesse Dukeminier, The Uniform Statutory Rule Against Perpetuities: Ninety Years in Limbo, 34 UCLA L. REv. 1023, 1031, 1034-36 (1987). I replied, demonstrating that the "dozen-healthy-babies ploy" would, statistically, produce a period of 113 years. See 
redivivus."79 Dukeminier says that "the only advantage of section 2707 is that it eliminates remainders from remaindermen's probate estates, possibly saving probate costs." 80 Then he adds that "[i]f there are probate administration costs associated with remainders, which have never been documented, they are a small price to pay for the flexibility of the common law."81

\section{A. Dukeminier's Case for Transmissible Future Interests and What's Wrong with $I t$}

Professor Dukeminier builds his case against section 2-707 on two main pillars: a defense of transmissible future interests, which in turn rests on what he calls the "flexibility of the common law," and his portrayal of the well-drafted trust. He also charges that section 2-707 is inconsistent with the modern trend toward increasing spousal protection and is not supported by empirical evidence.

\section{The "Flexibility" of Transmissible Future Interests?}

Professor Dukeminier argues that transmissible future interests have much-desired benefits, all of which are "upended" by section 2707. Dukeminier uses an "income to $A$ for life, remainder to $B$ " trust to illustrate these benefits. ${ }^{82}$ Although we shall see that even this example provides little real basis for his position, it is important to note that a simplistic income-to- $A$-for-life, remainder-to- $B$ trust, while occasionally useful in law school casebooks and classroom presentations, is seldom seen in real-world practice, and consequently is not the focus of section

Lawrence W. Waggoner, The Uniform Statutory Rule Against Perpetuities: The Rationale of the 90-Year Waiting Period, 73 CoRnell L. REv. 157, 160-62 (1988). Dukeminier never challenged the statistical evidence, but his casebook describes the $90-$ year period as "a close approximation of the "dozen or so healthy babies chosen from families noted for longevity.' " JESSE DUKEMINIER \& STANLEY M. JOHANSON, WiLLS, TRUSTS, AND ESTATES 887 (5th ed. 1995).

Dukeminier has labeled the USRAP as "an extraordinarily risky venture," "so bizarre that the mind boggles," "Waggoner's phantom ship," an idea that gives a "bizarre turn to perpetuities reform," and an act that is "deserving of oblivion." Dukeminier, supra, at 1024, 1025, 1068, 1069, 1079. USRAP has now been enacted in 24 states. Dukeminier's casebook mainly attributes USRAP's success to "a smooth selling job by the Uniform group." DUKEMINIER \& JOHANSON, supra, at 888.

78. Dukeminier, supra note 4 , at 150.

79. Id. at 166.

80. Id. (emphasis added).

81. Id. But see supra notes 53-60 and accompanying text on the costs of the "flexibility of the common law."

82. Dukeminier, supra note 4 , at 150-52. 
2-707. In the real world, cases like Krooss, ${ }^{83}$ Bomberger, ${ }^{84}$ Lawson, ${ }^{85}$ Gustafson, ${ }^{86}$ and $C o x^{87}$ demonstrate that future interests to which section 2-707 would apply arise in much more complicated trusts, and are usually contingent on multiple events, such as the life tenant and perhaps other remainder beneficiaries dying without issue. Nevertheless, for purposes of examining Dukeminier's avowed benefits of transmissible future interests, I will use his simplistic example. In that example, the common law would hold that $B$ has a transmissible future interest. If $B$ dies before $A, B$ 's future interest would pass through $B$ 's probate estate to his or her successors in interest $-B$ 's heirs or devisees. When $A$ subsequently dies, the future interest that $B$ 's successors in interest previously received from $B$ would become possessory. ${ }^{88}$

Section 2-707 would change that. Section 2-707 avoids tracing future interests through the probate estates of deceased persons. At $A$ 's death, the corpus always passes directly to living persons - to $B$ if still living; if not, to $B$ 's then-living descendants, ${ }^{89}$ if none, either to the persons who would be the donor's heirs if the donor died when $A$ died or to the donor's then-living residuary devisees and the then-living descendants of residuary devisees who had predeceased $A$.

The crux of Dukeminier's case against section 2-707 is that it deprives $B$ of the "flexibility" to "deal with changes in his family circumstances during the life tenant's life." 90 Dukeminier's claim is worth

83. In re Krooss, 199 N.E.2d 222 (N.Y. 1951).

84. In re Bomberger's Estate, 32 A.2d 729 (Pa. 1943).

85. Lawson v. Lawson, 148 S.E.2d 546 (N.C. 1966).

86. In re Gustafson, 547 N.E.2d 1152 (N.Y. 1989).

87. Cox v. Forristall, 640 P.2d 878 (Kan. Ct. App. 1982).

88. This assumes that all of $B$ 's successors in interest outlive $A$. If one or more of them die between $B$ 's death and $A$ 's death, the remainder interest must be traced through their estates to find out who owns the remainder interest, and in what proportions, at the distribution date. The possibility that some will die in the meantime is not imaginary. See, e.g., De Korwin v. First Natl. Bank, 179 F.2d 347 (7th Cir.), revg. on other grounds, 84 F. Supp. 918 (N.D. Ill. 1949), cert. denied, 339 U.S. 982 (1950); Peadro v. Peadro, 81 N.E.2d 192 (Ill. 1948); Gustafson, 547 N.E.2d at 1153.

89. Had the trust created a gift over, the gift over would take precedence over the substitute gift to $B$ 's descendants. For example, had the trust provided for the income to go to $A$ for life, remainder to $B$ if $B$ survives $A$, but if not to $C$, then if $B$ predeceased $A$ leaving descendants who survived $A$, and if $C$ also survived $A$, the corpus would go to $C$, not to $B$ 's descendants. To take it a step further, if $C$ also predeceased $A$, leaving descendants who survived $A$, the corpus would go to $B$ 's descendants, not to $C$ 's descendants. Finally, if $B$ or $C$ (but not both) left descendants who survived $A$, the corpus would go to those descendants. See UNIF. PROB. CODE \& 2-707 (1993); Halbach \& Waggoner, supra note 3, at 1131-47; supra note 17.

90. Dukeminier, supra note 4, at 150, 166. Dukeminier cites a 1969 article of mine that said pretty much the same thing. Id. at $151 \mathrm{n} .9$ (citing Lawrence W. Waggoner, Future Interests Legislation: Implied Conditions of Survivorship and Substi- 
repeating: Section $2-707$, he says, deprives $B$ of the "flexibility" to "deal with changes in his family circumstances during the life tenant's life"! Were it not for section 2-707, Dukeminier states that $B$ could "devise the remainder to $B$ 's spouse, taking advantage of the estate tax marital deduction, and making it possible for the spouse to use her $\$ 600,000$ exemption from the federal estate tax and $\$ 1$ million exemption from the generation-skipping transfer tax in transferring the trust property to their children." 91 Not noted by Dukeminier is the fact that under section 2-707, the property would not be taxable in either the predeceased remainder beneficiary's estate or in the beneficiary's surviving spouse's estate to begin with, hence freeing up other property that would be taxable in their estates for the marital deduction and the $\$ 600,000$ estate tax and the $\$ 1$ million generation-skipping transfer tax exemptions.

Never mind. Dukeminier continues: $B$ could "devise the remainder to $B$ 's children in such shares and on such terms as appear wise."92 Moreover, if $B$ 's children are minors, $B$ could "devise the remainder in trust for the children until they reach majority, avoiding conservatorship." 93 Finally, if one of $B$ 's children is disabled, $B$ could "devise the child's share in a trust providing the child only with benefits supplementing those the state provides, thus avoiding the state's seizure of the child's full share as the child's creditor, as section 2-707 would allow."94 Had the settlor been better advised, he or she would have given $B$ this flexibility by means of a power of appointment, but failing that, "[t]he transmissible vested remainder rule of the common law is a substitute for a power of appointment overlooked by the settlor." 95

There is much that is wrong with Dukeminier's claim that section 2-707 deprives the remainder beneficiary, $B$, of the "flexibility" to "deal with changes in his family circumstances during the life tenant's life." 96 First and foremost, the predeceased beneficiary of a transmissible future interest can only transmit a future interest, not a present interest. The recipient cannot derive much pleasure from a future interest until it ripens into possession. The recipient cannot use it for investment or consumption. The recipient cannot even hang it on the wall or place

tutionary Gifts Under the New Illinois "Anti-Lapse" Provision, 1969 U. ILL. L. F. 423, 438). Obviously I have changed my mind in the quarter century since I wrote that earlycareer article.

91. Id. at 151.

92. Id.

93. Id.

94. Id.

95. Id. at $150-51$.

96. Id. at 150 (emphasis added). 
it on the coffee table and admire its beauty. A future interest is of minimal financial (or aesthetic) value until the distribution date, i.e., until the trust is dissolved and the corpus is actually distributed.

Of course, the future interest does become valuable when the trust is dissolved and the corpus is actually distributed. But the remainder beneficiary cannot adjust for changes in his or her family circumstances that have occurred by that time. The remainder beneficiary can only take into account changes in family circumstances up to his or her own death. Only the life tenant can take into account changes in family circumstances occurring after the remainder beneficiary's death but before the distribution date. This explains why capable estate planners wanting to build flexibility into a trust give a power of appointment to the life tenant, not to the remainder beneficiary. ${ }^{97}$ When the remainder beneficiary dies, no one can predict when the distribution date will occur. Some life tenants die young, while others enjoy great longevity. The time between the remainder beneficiary's death and the distribution date might be considerable ${ }^{98}$ or brief. ${ }^{99}$ Much can happen during the interim. Significant changes can occur in the remainder beneficiary's family circumstances: By the time the distribution date comes about, the remainder beneficiary's surviving spouse might have remarried or died, the disabled child might have died or the laws dealing with supplementary trusts for disabled children might have changed, a healthy child might have become disabled or died, or a minor child might have reached adulthood or died. Indeed, the deceased remainder beneficiary might die unmarried and without issue and might even die long before reaching adulthood. ${ }^{100}$

Moreover, remainder beneficiaries are typically at least one generation younger than the life tenant. If that younger-generation remainder beneficiary writes a will - many die intestate ${ }^{101}$ — he or she is not likely even to consider the possibility of predeceasing the distribution date when writing that will. In addition, unlike Dukeminier's simplistic income-to- $A$-for-life, remainder-to- $B$ example, most future interests to which section 2-707 would apply are, like the ones in Krooss, ${ }^{102}$

97. See supra Part I.A; infra note 126 and accompanying text.

98. In Aufenkamp v. First Ky. Trust Co., 705 S.W.2d 943 (Ky. Ct. App. 1986), the gap was 41 years for one remainder beneficiary and 32 years for the other remainder beneficiary. The gap was 20 years in Saulsberry v. Second Natl. Bank, 400 S.W.2d 506 (Ky. 1966), and 11 years in Wade v. Bragg, 86 So. 2d 829 (Ala. 1956).

99. In Culver v. Culver, 425 A.2d 222 (Md. Ct. App. 1981), the gap was one year.

100. In Gist v. Brown, 113 S.E.2d 75 (S.C. 1960), the deceased remainder beneficiary who had a transmissible future interest died at age four.

101. See infra note 110 and accompanying text.

102. In re Krooss, 99 N.E.2d 222 (N.Y. 1951). 
Bomberger, ${ }^{103}$ Lawson, ${ }^{104}$ Gustafson, ${ }^{105}$ and Cox ${ }^{106}$ contingent on some event unrelated to survival (such as the life tenant and possibly other remainder beneficiaries dying without issue). The beneficiary might think that the chance of receiving any of the corpus is pretty remote. In Bomberger, for example, one of the remainder beneficiaries, John, died not only before the life tenant but also before his mother. ${ }^{107}$ His remainder interest was contingent on the life tenant dying without issue and on his mother predeceasing the life tenant. When John died, he might have expected the life tenant to die without issue, but he had no way of knowing that his mother would later predecease the life tenant. Moreover, the beneficiary might not understand that he or she "owns" a transmissible future interest at all. Even if the remainder beneficiary's attorney examines the trust document and recognizes that his or her client does or might "own" one, ${ }^{108}$ not much estate or tax planning can be done with an uncertain interest of uncertain value.

Whether the remainder interest is contingent or vested, the bottom line is that there is not much that the remainder beneficiary can do during the life tenant's life with a transmissible future interest to "deal with changes in his family circumstances," circumstances that might change in unpredictable ways between the beneficiary's death and the distribution date. Dukeminier cites no evidence, and my research of the case law uncovered none, that beneficiaries of transmissible future interests do any of the things that Dukeminier's article suggests. In the actual cases, the court either does not bother to disclose what happened to the transmissible remainder ${ }^{109}$ or does disclose that it passed through the beneficiary's estate by default, not by design - either because the remainder beneficiary died intestate ${ }^{110}$ or because the remainder beneficiary's will made no mention of the remainder interest and thus passed it,

103. In re Bomberger's Estate, 32 A.2d 729 (Pa. 1943).

104. Lawson v. Lawson, 148 S.E.2d 546 (N.C. 1966).

105. In re Gustafson, 547 N.E.2d 1152 (N.Y. 1989).

106. Cox v. Forristall, 640 P.2d 878 (Kan. Ct. App. 1982).

107. Bomberger, $32 \mathrm{~A} .2 \mathrm{~d}$ at 730.

108. Transmissible future interests are often omitted from the inventories and decrees of the remainder beneficiary's estate, leading to tracing costs. See, e.g., In re Latimer's Will, 63 N.W.2d 65, 72 (Wis. 1954).

109. See, e.g., Bomberger, $32 \mathrm{~A} .2 \mathrm{~d}$ at $730-31$.

110. The remainder beneficiary or beneficiaries died intestate in, for example, De Korwin v. First Natl. Bank, 179 F.2d 347 (7th Cir.), revg. on other grounds, 84 F. Supp. 918, 923 (N.D. Ill. 1949), cert. denied, 339 U.S. 982 (1950); Peadro v. Peadro, 81 N.E.2d 192, 193 (Ill. 1948); Saulsberry v. Second Natl. Bank, 400 S.W.2d 506, 507 (Ky. 1966); Detroit Bank \& Trust Co. v. Grout, 289 N.W.2d 898 (Mich. Ct. App.) (revocable trust), appeal denied, 409 Mich. 894 (1980); Boone County Natl. Bank v. Edson, 760 S.W.2d 108 (Mo. 1988); Dilts v. Clayhaunce, 62 A. 672 (N.J. Ch. 1906); Coddington v. Stone, 9 S.E.2d 420 (N.C. 1940); Gist v. Brown, 113 S.E.2d 75 (S.C. 1960). 
apparently unwittingly, under the will's catch-all clause, the residuary clause. ${ }^{11}$ Dukeminier cites no case, and I have found none, in which the remainder beneficiary singled out the remainder interest, deliberately passing it in or adding it to a marital deduction trust for his or her surviving spouse or a supplementary trust for a disabled child. ${ }^{112}$ Small wonder that - like section 2-707 - well-drafted trusts do not grant remainder beneficiaries the "flexibility" "to deal with changes in [their] family circumstances during the life tenant's life."

Dukeminier's disapproval of section 2-707 comes in sharp and mystifying contrast to his approval of a case that applied antilapse protection to an income interest in a trust. The case is Dewire v. Haveles, ${ }^{113}$ a case reproduced in his casebook. ${ }^{114}$ Thomas Dewire devised the residue of his estate in trust that was to terminate 21 years after the death of his last living grandchild. Upon termination, the corpus was to be distributed to "the lineal descendants of my grandchildren." 115 During the trust, the income was to be paid to the testator's widow for life, then to his son, Thomas, Jr. Thereafter, the income was to be "divided equally amongst [the testator's] grandchildren." 116 Nine years after Thomas, Jr.'s death, one of six grandchildren, Thomas III, died, survived by his widow and daughter, Jennifer. The other five grandchildren, the other income beneficiaries, were still living.

The question was what to do with the one-sixth share of income previously payable to Thomas III. "[T]he reasonable inference as to the testator's intention," the court concluded, "is that Jennifer should take her father's share in the income."117 Relying on the policy of the Massachusetts antilapse statute, the court fashioned a rule of construction requiring "(absent a contrary intent), the substitution of a class member's surviving issue for a deceased class member." 118 Although

111. The remainder beneficiary died with a will, but the transmissible remainder interest passed by default under the residuary clause, in for example, Boone County, 760 S.W.2d at 110; In re Krooss, 99 N.E.2d 222, 224 \& n.1 (N.Y. 1951), discussed in supra notes 19-23 and accompanying text; Elliott v. Griffin, 237 S.E.2d 396 (Va. 1977).

112. An occasional case is found in which the remainder beneficiary deeded the remainder interest to another or others. See, e.g., In re Clayton's Estate, 74 A.2d 1, 2 (Md. 1950); Davis v. Davis, 165 S.E.2d 553, 555 (N.C. Ct. App. 1969).

113. 534 N.E.2d 782 (Mass. 1989).

114. See DUKEMINiER \& Johanson, supra note 77 , at 812.

115. Dewire, 534 N.E.2d at 784 (internal quotation marks omitted).

116. 534 N.E.2d at 784 (internal quotation marks omitted).

117. 534 N.E.2d at 784 .

118. 534 N.E. $2 d$ at 785 n.5. Dewire is not the first case to reach such a result. For other cases in which the court construed a single-generation class gift of income to include the descendants of a deceased class member, see, for example, Cooper v. Birmingham Trust \& Sav. Co., 28 So. 2d 720 (Ala. 1947); Ryan v. Herbert, 47 A.2d 360 (Md. 1946); In re Estate of Camegie, 155 A.2d 349 (Pa. 1959). 
the court assumed that each grandchild's right to the income was only "a life interest," 119 the trust document apparently did not limit it to the life of each grandchild, and in such circumstances, there is a respectable position that the grandchild's income interest does not terminate on death but is for the entire term of the trust. ${ }^{120}$ Adopting this position would have allowed Thomas III to transmit his share of the income for the remaining period of the trust. Unlike a future interest, which is of minimal financial benefit to the recipient until the distribution date, an income interest is of considerable immediate benefit. All the tax and family planning that Dukeminier inappropriately attributes to transmissible future interests look more sensible when applied to transmissible income interests. One would expect Dukeminier to take the court to task for depriving Thomas III of the opportunity of deciding how best to provide for his own family - including the opportunity to benefit his surviving widow rather than his daughter - and for acting without empirical evidence. Not so. His Teacher's Manual states that "the result [of Dewire] makes good sense."121

\section{Powers of Appointment in Well-Drafted Trusts}

In a section titled "What a Skilled Estate Planner Would Do," 122 Professor Dukeminier follows up on his point that "[t]he transmissible vested remainder rule of the common law is a substitute for a power of appointment overlooked by the settlor" 123 by portraying good estate planning in a way that will bemuse my friends and colleagues who practice in this area, including the leading practitioners who serve on the Joint Editorial Board for the Uniform Probate Code. ${ }^{124}$ The following example is what Dukeminier says is a skilled work product:

Dukeminier's "Well-Drafted" Trust Case: $T$ devises a fund in trust "for $A$ for life, then to $B$ if $B$ survives $A$, and if $B$ does not survive $A$, then to such one or more of $B$ 's spouse and $B$ 's descendants and their

119. Dewire, 534 N.E.2d at 784; accord RESTATEMENT OF PROPERTY $§ 115$ (1936).

120. See Olin L. Browder, Trusts and the Doctrine of Estates, 72 MiCH. L. REv. 1507,1559 (1974).

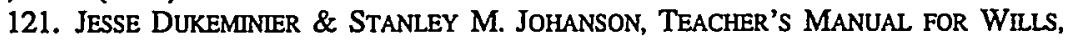
TRUSTS, AND ESTATES 217 (5th ed. 1995). THE RESULT OF Dewire is consistent with UPC § 2-707. In fact, § 2-707 would apply directly if each income payment is treated as a separate postponed class gift, as provided in the RESTATEMENT (SECOND) OF PROPERTY (DONATIVE TRANSFERS) $\S 26.2 \mathrm{cmt} . \mathrm{g}$ (1987). That approach would allow the substitute class to continue to rotate, so that on the death of the first substitute taker the income would be paid to his or her then-living descendants, and so on until the trust terminates.

122. Dukeminier, supra note 4 , at 163-65.

123. Id. at $150-51$.

124. See infra text accompanying notes $138-39$ for a description of their credentials. 
spouses as $B$ appoints by will. If $B$ fails to exercise the power of appointment, the trust property shall be distributed on $A$ 's death to $B$ 's descendants then living [or over to others]."125

Dukeminier's "well-drafted" trust case is a remarkable mischaracterization of good estate planning. Standard practice gives the power of appointment to the life tenant, not the remainder beneficiary. ${ }^{126}$ A capable estate planner, wishing to insert flexibility into a trust, never uses transmissible future interests and seldom thinks of giving a power of appointment to a remainder beneficiary, much less conditioning that power on the remainder beneficiary predeceasing the distribution date. ${ }^{127}$

There is something odd about Dukeminier's argument. Dukeminier appears to promote special powers for the remainder beneficiary rather than for the life tenant only when attacking UPC section 2-707.128 Dukeminier's casebook has a chapter entitled "Building Flexibility into

125. Dukeminier, supra note 4, at 164.

126. See supra text accompanying note 97 . In estate planning texts, it is usually assumed that the power of appointment will be given to the life tenant. The possibility of giving special testamentary powers to the remainder beneficiaries as a substitute for transmissible future interests is never given even passing consideration. See, e.g., JoHN R. Price, PRice ON Contemporary Estate PlanNing § 10.23 (1992) (stating that "[w]here it is consistent with the client's plan, a current beneficiary of the trust may be given a special power of appointment" and not mentioning the possibility of giving such a power to the remainder beneficiary) (emphasis added). Similarly, a recent article by two practicing lawyers argues for building flexibility into trusts by, among other things, giving a special power of appointment to the life tenant. They never even consider the possibility of giving powers to the remainder beneficiaries. See Neill G. McBryde \& Frederick R. Keydel, Building Flexibility in Estate Planning Documents, TR. \& EsT., Jan. 1996, at 56, 60.

In a footnote, Dukeminier treats the standard as exceptional and the exceptional as standard, by stating that a skilled estate planner "might" give the life tenant rather than the remainder beneficiary a power, but, he says, only if the life tenant "is competent and has sound judgment." Dukeminier, supra note 4, at 164 n.50 (emphasis added).

127. In Dukeminier, supra note 4, at 150 n.8, Professor Dukeminier cites an article by Professor Halbach in a way that leaves the impression that Halbach supports building flexibility into trusts by giving powers of appointment to remainder beneficiaries. Read in context, however, the Halbach article clearly supports giving the power to the life tenant. See Edward C. Halbach, Jr., The Use of Powers of Appointment in Estate Planning, 45 IoWA L. REv. 691, 692-93 (1960).

The only secondary authorities I found that suggest giving a power to remainder beneficiaries who predecease the distribution date are W. BARTON LEACH \& JAMES $\mathrm{K}$. logan, Cases and Text on Future Interests and Estate Planning 329 (1961); Verner F. Chaffin, Descendible Future Interests in Georgia: The Effect of the Preference for Early Vesting, 7 GA. L. REv. 443, 444-45, 490-91 (1973).

128. The only place in Dukeminier's casebook in which a remainder beneficiary is given a power of appointment is in a note declaring that "[i]f you want to give the remainderman power to transmit the future interest at death, give him a remainder contingent upon surviving plus a special power of appointment." DUKEMINIER \& JOHANSON, supra note 77, at 761 (first emphasis added). The only place in the casebook in which it 
Trusts: Powers of Appointment." ${ }^{29}$ If conferring a special power on each remainder beneficiary who predeceases the distribution date is what a skilled estate planner would do, one would expect his casebook chapter on powers to present that approach as a model of good estate planning. It does not. None of the illustrations in his casebook chapter on powers gives the remainder beneficiary a special power of appointment. Nowhere does that chapter promote the idea of giving the remainder beneficiary a special power in order to allow that beneficiary to adjust to changed family conditions. The power - hence the ability to adjust to changed family conditions - is always given to the life tenant.

But, we need not rely only on Dukeminier's chapter on powers of appointment to disprove his argument. If it were true that clients were clamoring for trusts giving powers of appointment to remainder beneficiaries who predecease the distribution date rather than to life tenants, one would expect the form books to be full of such forms. They are not. I am unaware of any form book giving a remainder beneficiary who predeceases the distribution date a power of appointment over the remainder interest. ${ }^{130}$

The reasons why powers of appointment are not commonly given to remainder beneficiaries who predecease the distribution date are the same reasons why transmissible future interests do not have the advantages attributed to them by Dukeminier: If the remainder beneficiary predeceases the life tenant, the remainder beneficiary's will can only

is presented as a good idea to do this is in the note attacking UPC \& 2-707 that formed the basis for his Upending Remainders article. See id. at 788-92.

129. Id. at 701-45.

130. I do not want to be understood as saying that no settlor has ever conferred a power of appointment on a remainder beneficiary that is contingent on the remainder beneficiary predeceasing the distribution date. I am merely saying that it would be unusual to do so, and that no form book of which I am aware contains any such form. See

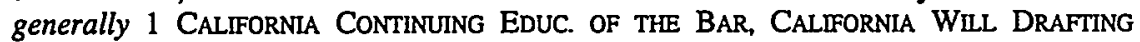
$\S 16.38$ (1992); 3 id. app. E, form 19.21-1; Drafting California Revocable Living TRusts $\$ \S 14.17-.22$ \& forms A-G (John R. Cohan ed., 3d ed. 1994); U.S. TRUST Co., PRACTICAL DRAFTING: Will PROVISIONS form G-2c, at 27, form H-4d, at 36-37, form H-Se, at 40-41 (1995); U.S. TRUST Co., PRACTICAL DRAFIING: TRUST Provisions form C2, at 5, form C-4c, at 7, form C-5d, at 11, form C-7e, at 24, form D-7c, at 65 (1995).

Certainly, if the settlor wants the remainder beneficiary to have control of the disposition of his or her future interest on the distribution date if the remainder beneficiary dies earlier, the settlor would be better advised to confer a power of appointment on the remainder beneficiary rather than a transmissible future interest.

Moreover, in standard trusts giving the life tenant a power of appointment, settlors might be well-advised to protect against the life tenant losing capacity to exercise the power by granting each remainder beneficiary a special power over his or her remainder interest. This power, however, would not be contingent on the remainder beneficiary predeceasing the distribution date. 
appoint a future interest to the appointees, an interest that cannot benefit the appointees before the life tenant dies, and cannot take into account changes in family conditions occurring between the remainder beneficiary's death and the life tenant's death. In fact, the remainder interest might not ever benefit the appointees because it might be contingent on some event that does not happen, such as another person dying without issue.

\section{Inconsistency with the UPC's Increased Spousal Shares?}

Professor Dukeminier makes another argument. He claims that section 2-707 is somehow inconsistent with other major themes of the 1990 UPC revisions, specifically the decision to increase the intestate share of a surviving spouse and the revision of the spouse's elective share. Dukeminier writes: "It seems particularly odd that the UPC revisers in section 2-707 make it impossible for $B$ to benefit $B$ 's spouse any longer, inasmuch as the modern trend is to increase the protection of the spouse." 131

Dukeminier's argument confuses the settlor's intent with the remainder beneficiaries' intent and the rights of the remainder beneficiaries' spouses, such as the settlor's sons-in-law or daughters-in-law. UPC section 2-707 seeks to implement the settlor's intent. In today's divorce-prone and blended-family world, the evidence indicates that settlors incline toward substituting the descendants, not the spouse, of a remainder beneficiary who predeceases the distribution date. ${ }^{132}$ During the developmental stage of section 2-707, I brought to the Board a draft that would have substituted the persons who would be the predeceased remainder beneficiary's "heirs" if the remainder beneficiary died on the distribution date, rather than his or her "descendants" surviving the distribution date. Substituting the remainder beneficiary's distribution-date heirs would have included his or her surviving spouse (assuming that the beneficiary's spouse was still living at the distribution date and had not remarried). The practitioners on the Board rejected this version on the ground that it would not carry out common intent. ${ }^{133}$

131. Dukeminier, supra note 4 , at 151 . Dukeminier cites as exemplifying this modem trend the UPC's provisions "relating to intestacy and the elective share." Id. at 152 (footnote omitted).

132. See also infra notes $138-40$ and accompanying text (describing the preference of leading practitioners for substituting descendants). Settlors who do want to allow sons-in-law or daughters-in-law to benefit (and some do) indicate this affirmatively by granting the life tenant a special power to appoint among descendants and spouses of descendants.

133. Cf. infra notes $138-40$ and accompanying text (describing view of other estate experts that $\S 2-207$ furthers, not impedes, settlor's intent). 
As for the modern trend toward increasing the protection for surviving spouses, that trend relates to the property of the deceased spouse, not to trusts created by someone else, such as the parent or grandparent of the deceased spouse. Neither the UPC nor any other probate code grants an intestate share to sons-in-law or daughters-in-law, or to any other relative by marriage, nor does it grant them an elective share in the property of anyone other than their own spouses. ${ }^{134}$

\section{No Empirical Evidence?}

Professor Dukeminier accuses the UPC revisers of acting without empirical evidence. ${ }^{135}$ Although it is true that there is no systematic empirical study supporting section $2-707,{ }^{136}$ Dukeminier's claim that "[ $[$ ]he [UPC] drafters appear to be proceeding purely on their own speculation" 137 is wholly unjustified. Indeed, requiring a systematic empirical study before any reform can be put into place would paralyze the lawreform process. Neither the Uniform Law Commission nor the American Law Institute, the two premier national organizations devoted to law reform, has funding for such studies. Dukeminier's claim might be justified if the law-reform process were in the hands of amateurs who know little about the field or the practice. In the specific case of the UPC revisions, the process is in knowledgeable and experienced hands. There is also plenty of evidence that capable estate planners, acting for their clients, avoid transmissible future interests like the plague, and that they ordinarily create remainders in the form of multiple-generation class gifts with a survival requirement, which automatically substitute a remainder beneficiary's descendants rather than his or her successors in interest if the remainder beneficiary predeceases the distribution date.

In addition, I feel compelled to add that the Joint Editorial Board for the Uniform Probate Code, ${ }^{138}$ the principal revisers of the UPC, is an organization that counts among its members not only leading scholars in the field but also nationally known estate planners of considerable insight and experience. Specifically, Board membership includes

134. The UPC's elective share includes in the property subject to that share (called the "augmented estate") property over which the decedent spouse had a general power of appointment in a trust created by someone else, but only if the general power is expressly created and only if the general power is presently exercisable. See UNIF. PROB. CODE \& 2-205(1)(i) (1993).

135. See Dukeminier, supra note 4 , at 149.

136. Nor is there a systematic empirical study supporting the common law judges who in centuries past and for now-outdated reasons established the rule of early vesting that produces transmissible future interests.

137. Dukeminier, supra note 4 , at 149-50.

138. See supra note 2. 
four past presidents and the president-elect of the American College of Trust and Estate Counsel, four past chairs of the ABA Section of Real Property, Probate and Trust Law, and the current president and a past president of the International Academy of Estate and Trust Law, not to mention the Reporter for the Restatement (Third) of Trusts and the Reporter and Associate Reporter for the Restatement (Third) of Property (Donative Transfers). Their cumulative experience suggests that they have a pretty good idea of what most clients want.

I might also add that two other groups of leading practitioners, academics, and judges have, without dissent, recommended that the Restatement (Third) of Property (Donative Transfers), a project of the American Law Institute in process, include a section similar to section 2-707, substituting the descendants of remainder beneficiaries who predecease the distribution date. ${ }^{139}$

Lawyers experienced in drafting real trusts for real clients appear to think that section 2-707 is intent-effecting, not intent-defeating. ${ }^{140}$

\section{B. Why the UPC Did Not Give Remainder Beneficiaries Who} Predecease the Distribution Date a Power To Appoint the Remainder Interest

Building on the dual but questionable propositions that "[t]he transmissible vested remainder rule of the common law is a substitute for a power of appointment overlooked by the settlor" 141 and that skilled estate planners give remainder beneficiaries rather than life tenants a power to appoint the remainder interest, Professor Dukeminier cites an article by Professor Susan French, a colleague of his at the UCLA School of Law. ${ }^{142}$ French's article acknowledged that most com-

139. The two groups are the Members Consultative Group (MCG) for and the Advisers to the Restatement (Third) of Property (Donative Transfers). The recommendations came at the MCG meeting of September 29, 1995, and at the Advisers' meeting of October 26, 1995. The credentials of these two groups of experienced practitioners, judges, and legal-academics match up very well with those of the Joint Editorial Board. There is in fact some overlap between the groups. Eight of the 23 Advisers are members of or associated with the Joint Editorial Board.

140. See supra notes $132-33$ and accompanying text.

141. Dukeminier, supra note 4 , at 151-52.

142. See id., at 165 n.52 (citing Susan F. French, Imposing a General Survival Requirement on Beneficiaries of Future Interests: Solving the Problems Caused by the Death ' of a Beneficiary Before the Time Set for Distribution, 27 ARIz. L. REV. 801 (1985)). Dukeminier miscites the French article as one that "compared [the early vesting rule and the antilapse-type rule] to what skilled estate planners do in creating trusts." Id. at 165 . The French article did advance her personal view that giving a deceased remainder beneficiary a special power would be preferable to either rule, but did not base this idea on or present any empirical evidence that this is "what skilled estate 
mentators favor a statute like section 2-707, but she proposed a modification of that idea under which the beneficiary of a future interest who predeceased the distribution date would be given a power of appointment. ${ }^{143}$ In Upending Remainders, Dukeminier embraces the French proposal, describing the French article as "the most comprehensive examination of whether an antilapse statute is preferable to the common law of remainders." 144

The French power-of-appointment proposal (now the DukeminierFrench proposal) was not overlooked in the process of drafting section 2-707. The proposal was not adopted for three reasons. First, the theoretical basis for the proposal is questionable. Second, the proposal would add an additional layer of complexity to an already intricate statute. Third, the number of remainder beneficiaries who would actually exercise the power would be few and far between.

The settlor's intent controls the construction of trusts, ${ }^{145}$ not the remainder beneficiary's intent. To be persuasive, the Dukeminier-French proposal for replacing transmissible future interests with special powers of appointment in predeceasing remainder beneficiaries must be grounded in the view that settlors deliberately create transmissible future interests. The actual case law, ${ }^{146}$ the scholarship, ${ }^{147}$ and the practice of capable estate planning attorneys ${ }^{148}$ make that proposition highly questionable. It appears far more likely that transmissible future interests are created by accident, by inadvertence, by drafting error.

Even if it were true that settlors deliberately create transmissible future interests, the idea of statutorily conferring a power of appointment on deceased remainder beneficiaries is not as easily implemented

planners do in creating trusts." Dukeminier himself presents no empirical evidence that this is "what skilled estate planners do in creating trusts." Id. And, of course, this is not what skilled estate planners do in creating trusts. See supra note 126 and accompanying text. Despite the lack of empirical evidence supporting his assertions, Dukeminier charges "[t]he [UPC] drafters" with acting without empirical evidence and says that they "appear to be proceeding purely on their own speculation." Dukeminier, supra note 4, at 149-50.

143. See French, supra note 142, at 826. The article was prepared for but apparently not acted upon by the California Law Revision Commission. In his casebook, Dukeminier portrays French's proposal as "brilliant." See DUKEMINIER \& JOHANSON, supra note 77, at 791 .

144. Dukeminier, supra note 4 , at 165 .

145. See REstatement (THIRD) OF PROPERTY (DONATIVE TRANSFERs) $\$ 10.1$ (Tentative Draft No. 1, 1995) ("The controlling consideration in determining the meaning of a donative document is the donor's intention."). This was approved by the American Law Institute at the 1995 Annual Meeting. 72 A.L.I. PROC. (1996).

146. See supra notes $18-60$ and accompanying text.

147. See supra section I.C.

148. See supra notes 9-14 and accompanying text. 
as it appears, nor as simple as Dukeminier's article claims. It would not be enough to confer a power of appointment on deceased remainder beneficiaries and let it go at that. Because actual trusts are far more complicated than the simplistic income-to- $A$-for-life, remainder-to- $B$ example, the statute would still have to establish a set of priorities to determine which remainder beneficiary in a series of alternative remainder interests has the power and under what circumstances. French understood this point. Her article states:

[I] $\mathrm{f}$ the language [of a disposition] states that there is a remainder to $A$, but if $A$ dies without issue, to $B$, the statute should subject $A$ to a general survival requirement. If $A$ dies without issue, the instrument substitutes $B$ for $A$. The statute imposes a general survival requirement on $B$, so that if $B$ dies before distribution, the statutory substitution for $B$ will be made. On the other hand, if $A$ dies with issue, the statutory substitution for $A$ will be made (since the instrument provides no substitute for this event). ${ }^{149}$

When French uses the term "statutory substitution," she refers to the deceased remainder beneficiary's appointee or, in the absence of an appointment, the statutory takers in default. Although French did not draft statutory language that would implement this plan - describing what result a statute should reach in a particular case is considerably easier than drafting a statute that reaches that result in that case without mishandling other, unanticipated cases - section 2-707 does precisely that, except that the "statutory substitution" under section 2-707 is the remainder beneficiary's descendants who survive the distribution date. ${ }^{150}$

Implementing the Dukeminier-French power-of-appointment proposal would therefore not simplify section 2-707, but would complicate it. The statute would still have to provide for substituting descendants in case the power was not exercised. In addition, on the basis of the case law, it appears that few, if any, deceased remainder beneficiaries would be found to have exercised the power. French states (and Dukeminier would presumably agree) that exercise of the statutorily conferred power should "require[] an affirmative manifestation of intent." 151 She suggests that a regular residuary clause should not be taken as manifesting such an intent, ${ }^{152}$ and certainly dying intestate would not manifest

149. French, supra note 142 , at $833-34$.

150. See supra notes $7,17,69 \& 89$ and accompanying text.

151. French, supra note 142 , at 821 .

152. She suggests that "blanket exercises," but not regular residuary clauses, "should be sufficient." Id. (citing Edward H. Rabin, Blind Exercises of Powers of Appointment, 51 CORNELL L.Q. 1 (1965)). A "blanket exercise" clause is a residuary clause that purports to devise the residue of the testator's estate "and any property over which I have a power of appointment." See Rabin, supra, at 1. 
such an intent. Under the case law, transmissible future interests usually pass under regular residuary clauses or by intestacy. ${ }^{153}$ Consequently, few remainder beneficiaries would be found to have exercised the power.

In addition, the Dukeminier-French power-of-appointment proposal opens up a series of additional questions not easily resolved or, once resolved, controlled by unambiguous statutory language. Dukeminier acknowledged only a few of these questions. French did acknowledge and discuss some of them, but did not decisively resolve them all. Here are a few of the unanswered questions that come to mind: Should the beneficiary have the power only if the beneficiary left surviving descendants? A surviving spouse? Surviving when, surviving the beneficiary or surviving the distribution date? Should the power be presently exercisable, or only testamentary? How broad should the objects of the power be? Should the spouse be included, or only descendants? Should the spouse only be included if the beneficiary also left surviving descendants? Should the spouse only be included if the beneficiary left surviving descendants and those descendants were also descendants of the surviving spouse? What language in the beneficiary's will should exercise the power? A regular residuary clause? A blanket-exercise clause?

If the beneficiary did exercise the power, should the beneficiary's appointees be required to survive the distribution date? What if one or more of the beneficiary's appointees survived the beneficiary but predeceased the distribution date? ${ }^{154}$ Should those appointees, now beneficiaries of the trust, also be given a power of appointment? Who should take in default of the appointee's exercise of the power? The appointee's descendants who survive the distribution date? Or the original remainder beneficiary's descendants who survive the distribution date? What if neither the appointee nor the original remainder beneficiary had descendants who survived the distribution date?

As these and many other questions would be considered and resolved, and the draft language tested against a variety of fact situations, other questions would surely surface as the beleaguered drafters sought to deal with the various permutations of possible future events. Reducing all these choices to statutory language would cause the statute to

153. See supra notes 110-11 and accompanying text.

154. In the cases cited supra note 88 , one or more of the deceased remainder beneficiaries' successors in interest also predeceased the distribution date. Take the simplistic income-to- $A$-for-life, remainder-to- $B$ trust. Suppose that $B$ predeceases $A$, exercising the power in favor of $C$. Suppose that $C$ also predeceases $A$. Is $B$ 's exercise ineffective because his appointee did not survive the distribution date, or does $C$ have a power over her remainder interest? 
grow ever larger in size and complexity and increase the possibility of ambiguity and oversight.

A final point is this. Transmissible future interests have three disadvantages: (1) the remainder interest is included in the predeceased beneficiary's gross estate for federal estate tax purposes; (2) the remainder interest must be traced through the predeceased beneficiary's probate estate to identify the beneficiary's successors in interest, and track them down to see where they are and whether any have died in the meantime (and if so, trace through their probate estates); and (3) the remainder interest might end up outside the family or bloodlines. Section 2-707 in its current form solves all three problems: The remainder interest is not taxed in the remainder beneficiary's estate, does not have to be traced through the remainder beneficiary's estate or any intermediate estates, and does not pass outside blood (or adopted) lines of descent. Conferring a special power on the remainder beneficiary prevents the property from being taxed in the remainder beneficiary's estate, ${ }^{155}$ but it does not avoid tracing to see whether the power was exercised and to whom, and possibly tracing through additional estates if one or more appointees predeceased the distribution date. Nor does it necessarily prevent the property from passing outside the family or bloodlines. That possibility would depend on the identities of the objects of the power and of the appointees, and, should one or more appointee also predecease the distribution date, that appointee's appointees or successors in interest. Moreover, this proposal also opens the potential for litigation over the issue of whether the remainder beneficiary's will did in fact exercise the power in borderline cases.

\section{Supposed PRoblems WITH SECTION 2-707}

After testing UPC section 2-707 against the actual case law, rather than against a set of stacked hypothetical trusts of the type featured in Professor Dukeminier's article, Professor Edward Halbach and I concluded:

[N]o statute, no matter how deliberative or skillful the drafting process, can be expected to give a satisfactory outcome to every conceivable set of facts that may arise or that can be imagined by fertile minds. Every statute will give a bad result from time to time. The only reasonable test of a new statute is whether it advances the law by giving a satisfactory result in a greater proportion of cases than the law it replaces and

155. Property subject to a special power of appointment is not included in the powerholder's gross estate, but an exercise might subject it to the generation-skipping transfer tax. See I.R.C. $\$ \S 2041,2601$ (1994). 
whether it does so with a minimum of litigation. Obviously, the framers believe that [UPC section 2-707] meet[s] this test and, once enacted, will serve the public well. ${ }^{156}$

Ignoring this test, Dukeminier presents a group of outlier cases in an effort to give section 2-707 the appearance of inept draftsmanship and unjust application. I will discuss only a selection of these charges, to give the reader an idea of the type of claims he makes. To unravel the errors in every one of his claims would unduly extend the length of this article and stretch the reader's patience - not to mention my own.

\section{A. Adverse Tax Implications?}

Casting his now-familiar but simplistic and rarely seen income-to$A$-for-life, remainder-to- $B$ trust in the form of an irrevocable inter vivos trust, Professor Dukeminier attempts to show that section 2-707 can create an unjust result and cause unnecessary taxation. In order to make section 2-707 appear to work these injustices, he poses a fact situation in which $B$ predeceases $A$ without leaving any descendants surviving $A$ and the settlor survives $B$ but predeceases $A$. In this scenario, Dukeminier claims that section 2-707 creates two problems. It deprives the settlor of the opportunity to decide where the property should go when $A$ dies and it might cause the property to be taxed in the settlor's estate under section 2037 of the Internal Revenue Code. ${ }^{157}$

Dukeminier is quite wrong on both counts. His analysis is based on a fundamental misunderstanding of what section 2-707 does. His error occurs when he says that "the settlor has a reversion" 158 if $B$ dies without descendants surviving the distribution date. Section 2-707 does not give the settlor a reversion in that instance or in any other circumstance. In effect, what section 2-707 does is to transform the remainder interest from one that is indefeasibly vested in $B$ into one in favor of $B$ if $B$ survives $A$, but if not to $B$ 's descendants surviving $A$, and if none to those persons who would be the settlor's heirs if the settlor died when $A$ dies. ${ }^{159}$ Under section $2-707$, the property would not revert to the settlor even if the settlor survived $A .{ }^{160}$ Nor would the settlor want it to, for $i r-$ revocable inter vivos trusts are normally created for tax reasons - to subject the creation of the trust to the gift tax, avoiding the estate tax.

156. Halbach \& Waggoner, supra note 3 , at 1149.

157. See Dukeminier, supra note 4 , at 156-57.

158. Id. at 157.

159. See UNIF. PROB. CODE $\S \S 2-707(b)(1)$, (d)(2); 2-711 (1993).

160. There is nothing in UPC $\$ 2-711$ preventing it from determining the persons who would be the settlor's heirs at the distribution date, even if the settlor is then still alive: See UNIF. PROB. CODE § 2-711 (1993). 
Irrevocable inter vivos trusts lose their tax advantage if the settlor retains a power or property interest in the trust. Section 2-707 is quite consistent with the tax objective normally associated with irrevocable trusts. The settlor has already paid a gift tax when creating the trust (or used up some of his or her unified credit); the last thing that the settlor wants is to get the property back, potentially subjecting the property to a second transfer tax when he or she later disposes of it by gift or will. Dukeminier is quite wrong when he says that the property is included in the settlors's gross estate under section 2037 if the settlor dies before $A$.

Dukeminier's intent analysis is also quite flawed. It creates a false choice. Dukeminier claims that section 2-707 deprives the settlor of the ability to decide who should get the property when $A$ dies. ${ }^{161}$ But neither the common law nor Dukeminier's power of appointment proposal gives the settlor that choice. Both would give the choice to $B$. Without section 2-707, the remainder would pass through $B$ 's estate, even though $B$ 's descending line had died out by the distribution date. UPC section 2-707 avoids that result and instead gives the property at $A$ 's death to the persons who would be the settlor's heirs if the settlor died when $A$ died. These persons are, after all, the settlor's closest living relatives as of the date when the trust is dissolved and the property is distributed, and it seems reasonable to give the property directly to the settlor's closest living relatives when $A$ dies.

On another tax point, Dukeminier acknowledges that section 2-707 prevents the remainder interest from being taxed in the predeceased beneficiary's gross estate under the estate tax, but he also states that section 2-707 can cause the trust property to be taxed under the federal generation-skipping transfer tax (GST tax). ${ }^{162}$ The GST tax would apply to the extent that "skip persons" (beneficiaries who are more than one generation below the transferor) receive the property on the distribution date. The GST tax, however, only applies to larger estates. Each donor has a $\$ 1$ million GST exemption. ${ }^{163}$ Even Dukeminier concedes that

161. Dukeminier states:

Where an inter vivos trust fails for some reason, and a resulting trust or equitable reversion arises in the settlor, the settlor has a second chance to fill a gap in the disposition or to correct otherwise the flaw in the original trust. Under section 2707 , the settlor cannot say what is to be done with the property unless the settlor survives the termination of the trust. Why the 1990 UPC revisers chose to pass the property upon the termination of the trust to the settlor's heirs, who might not be the objects of the settlor's bounty, rather than in accordance with the settlor's direction in his will or through his residuary clause is inexplicable.

Dukeminier, supra note 4, at 157.

162. See id. at 163.

163. See I.R.C. § 2631 (1994). 
"numerous factors may come into play in any individual case" and therefore "it is not possible to say whether the present transmissible remainder rule or section 2-707 will be more advantageous to taxpayers." 164 Because section 2-707 only applies to poorly drafted trusts, however, it is doubtful that very many trusts covered by section 2-707 will exceed the GST exemption amount of $\$ 1$ million per donor. ${ }^{165}$

\section{B. Distinguishing "Legal" from "Equitable" Remainders?}

Section 2-707 only applies to future interests "under the terms of a trust." 166 The rationale, explained in the Official Commentary, is to prevent the statute from interfering with the possibility of a life tenant and remainderman of a nontrust disposition of land joining together to sell the land in fee simple absolute. ${ }^{167}$

Professor Dukeminier asserts that restricting section 2-707 to trust future interests "may revive old learning, thought obsolescent, about whether the Statute of Uses applies to the particular [trust] instrument and converts legal interests into equitable ones," and may make it necessary to determine whether a trust document creates a "legal" or "equitable" remainder. ${ }^{168}$ Section $2-707$, however, is not restricted to equi-

164. Dukeminier, supra note 4 , at 163.

165. Even in the rare case of UPC § 2-707 applying to a trust large enough in value to be potentially subject to the GST tax, there may be occasional relief coming in the form of an amendment to the "predeceased-ancestor" exception of the GST tax. Under the "predeceased-ancestor" exception, a transfer to a grandchild of the transferor or of the transferor's spouse or former spouse is not treated as a particular type of generation-skipping transfer called a "direct skip" if, "as of the time of the transfer," the grandchild's parent is dead. See I.R.C. $\S 2612$ (c)(2) (1994) (emphasis added). The transfer to a beneficiary more than one generation below the transferor taking place when a trust is distributed is a different type of generation-skipping transfer called a "taxable termination." Bills pending in Congress extend the predeceased-ancestor exception to all types of generation-skipping transfers, including taxable terminations. In order to apply to a taxable termination, however, the grandchild's parent must have been dead when the trust was created; the exception would still not apply if the parent was living when the trust was created but died before the distribution date. See H.R. 2491, 104th Cong., 1st Sess. $\S 14634$ (passed by the House on Oct. 26, 1995); S. 1357, 104th Cong., 1st Sess. $\S 12304$ (passed by the Senate on Oct. 27, 1995).

166. UNIF. PROB. CODE $§ 2-707(b)$ (1993).

167. See UNIF. PROB. CODE $§ 2-707 \mathrm{cmt}$. (1993). A state with a suitable statutory provision authorizing a life tenant to give a fee simple title might consider lifting the restriction to trust future interests. See, e.g., MiCH. CoMP. LAws $§ 600.2930$ (1979); N.Y. REAL PROP. ACTS. LAW $\S \S 1602-1613$ (McKinney 1979); LEWIS M. SIMES \& ClaRENCE B. TAYLOR, IMPROVEMENT OF CONVEYANCING BY LEGISLATION 237 (1960); William F. Fratcher, A Modest Proposal for Trimming the Claws of Legal Future Interests, 1972 DUKE LJ. 517.

168. Dukeminier, supra note 4 , at 160. 
table remainders as such. ${ }^{169}$ The section only applies to future interests "under the terms of a trust," a defined term making it clear that section 2-707 applies if the future interest was created by the "terms" of a trust. ${ }^{170}$ The question here is whether a trust document (or, in the rare case of an oral trust of personal property, whether the terms of the oral trust) created the future interest, not whether the future interest created by the trust document is "legal" or "equitable."171 Contrary to Dukeminier's claim, section 2-707 does not revive "old learning, thought obsolescent," nor does it distinguish between "legal" and "equitable" remainders.

\section{Trust Termination Before the Distribution Date Made More Difficult?}

Under American law, the beneficiaries of a trust can join together to terminate a trust before the distribution date. Doing so requires the consent of all possible beneficiaries and proof that no "material purpose" of the trust would be defeated by the premature termination. ${ }^{172}$ Citing once again the simplistic but unrealistic income-to- $A$-for-life, remainder-to- $B$ trust, Professor Dukeminier asserts that "[s]ection 2-707 makes it more difficult to terminate trusts." 173 Theoretically, Dukeminier is correct because section 2-707 creates a substitute future interest in remainder beneficiaries' descendants, a class that includes potentially unborn persons who cannot give the required consent. As a practical matter, however, the point is not as significant as Dukeminier makes it appear. Even under current law, very few trusts can be termi-

169. The term equitable future interest never appears in the statutory text or official commentary to $\$ 2-707$.

170. See UNIF. PRoB. Code § 2-707(a)(6) (1993).

171. See RestatemeNT (ThIRD) OF TRUSTS $\& 4$ (Tentative Draft No. 1, 1996) (defining "terms of the trust" as "the manifestation of intention of the settlor with respect to the trust provisions expressed in a manner that admits of its proof in judicial proceedings") (emphasis added); see also id. cmt. c ("If a trust is created by will, the terms of the trust are determined by the provisions of the will ...."); id. cmt. d ("If a trust is created by a transaction inter vivos and is evidence by a written instrument, the terms of the trust are determined by the provisions of the governing instrument . . . ."); id. cmt. e " If a trust is created by a transaction inter vivos and is not evidenced by a written instrument, the terms of the trust are determined by such evidence of the intention of the settlor with respect to the trust as is not barred from consideration because of a Statute of Frauds or some other rule of law."); id. cmt. $\mathrm{f}$ ("If a trust is established by an order of court and is to be administered as an express trust, the terms of the trust are determined by the provisions of the court order ...."). This was approved by the American Law Institute at the 1996 Annual Meeting. 73 A.L.I. PROC. (forthcoming 1997).

172. See Restatement (SECOND) OF TRUSTS $\S 337$ (1957).

173. Dukeminier, supra note 4 , at 159. 
nated before the distribution date. The usual rule is that spendthrift trusts, discretionary trusts, trusts for support, and postponement-of-enjoyment trusts contain a "material purpose" and cannot be terminated. ${ }^{174}$ Typical trust forms include a boilerplate spendthrift provision, and many trusts grant discretionary powers or discretionary-support powers to the trustee. In addition, most trusts create future interests in classes that are still subject to open, thus preventing premature termination. The fact that section 2-707 creates a substitute gift to descendants of remainder beneficiaries who predecease the distribution date does not make many trusts nonterminable that were not otherwise nonterminable anyway.

Of course, giving the remainder beneficiary a special power, as Dukeminier suggests, would not solve the trust termination problem, either. As pointed out above, the statute would still have to name takers in default, a group that would include potentially unborn persons. The takers in default of a special power are counted as trust beneficiaries who must give their consent to the termination of the trust. ${ }^{175}$

In any event, there is an easy solution to the trust termination problem. It is to add a section resembling the California statutory provision that permits a guardian ad litem to consent to termination or modification on behalf of "a beneficiary who lacks legal capacity, including a minor, or who is an unascertained or unborn person." 176 In writing the Official Commentary to section $2-707$, I probably should have recommended enactment of a provision similar to that California provision. When the Uniform Probate Code revisions were in process, the Uniform Law Commission was expected to begin work on a Uniform Trust Act that would incorporate such a provision. As it has turned out, the Uniform Trust Act project was delayed, although it is now under way and will almost certainly include such a provision.

\section{More Perpetuity Violations?}

Professor Dukeminier asserts that section 2-707 will cause perpetuity violations. The example he gives is hardly a real-world ex-

174. See DUKEMINIER \& JOHANSON, supra note 77 , at 658 ("Generally, a trust cannot be terminated if it is a spendthrift trust, if the beneficiary is not to receive the principal until attaining a specified age, if it is a discretionary trust, or if it is a trust for support of the beneficiary.").

175. See Eugene F. SColes \& Edward C. Halbach, JR., Problems and Materials ON DECEDENTS' ESTATES AND TRUSTS 481 (5th ed. 1993).

176. CAL PROB. CODE $\S 15405$ (West 1991); see also Hatch v. Riggs Natl. Bank, 361 F.2d 559 (D.C. Cir. 1966) (authorizing the appointment of a guardian ad litem to represent unborn and unascertained beneficiaries). 
ample: "For $A$ for life, then to $A$ 's children for their lives, then to $B$. ." 177 As with his income-to- $A$-for-life, remainder-to- $B$ example, a two-generation trust with an indefeasibly vested remainder to a named individual is occasionally useful in law school casebooks and classroom presentations. But as a real-world trust that responsible legislative drafters have to be concerned about, I have trouble taking this example seriously. What rational person would want to name a remainder beneficiary who is almost certain to be deceased at the distribution date, without providing for an alternative remainder, such as one to $B$ 's descendants surviving the distribution date?

In any event, in analyzing his two-generation trust with an indefeasibly vested remainder to a named individual, Dukeminier assumes that the common-law Rule Against Perpetuities governs the case. He properly points out that section 2-707 does not cause $B$ 's remainder to violate the common-law Rule, but instead creates a substitute gift in $B$ 's descendants that would violate the Rule and be void. Dukeminier neglects the fact that the Uniform Probate Code is an integrated code. Most provisions are drafted on the assumption that every other provision has been enacted. The Code contains the freestanding Uniform Statutory Rule Against Perpetuities (USRAP), ${ }^{178}$ under which the substitute gift to $B$ 's descendants would not be void ab initio, but would be given ninety years in which to vest. ${ }^{179}$ And a few other states have enacted a different version of the wait-and-see approach or have adopted some other provision that liberalizes the common-law Rule. Under USRAP, if $A$ 's last surviving child dies within ninety years, the substitute gift would be valid. If $A$ 's last surviving child lives beyond ninety years, the substitute gift would still not be invalid; the gift would be judicially reformed to give a vested interest to $B$ 's descendants living ninety years after the trust was created. ${ }^{180}$

177. Dukeminier, supra note 4, at 159 (internal quotation marks omitted).

178. See UNIF. PROB. CODE $\S \S 2-901$ to -907 (1993). The USRAP has been enacted in 24 states.

179. See UNIF. ProB. CODE § 2-901(a)(2) (1993).

180. See UNIF. PROB. CODE $\S 2-903$ (1993). Dukeminier does not mention that the USRAP is part of the Uniform Probate Code. He does, however, misleadingly portray what would happen "if" the jurisdiction has adopted USRAP. See Dukeminier, supra note 4 , at 159 . He asserts that the outcome of a reformation suit would be "[un]predictable" and "a godsend to lawyers." Id. As pointed out in the text above, however, the outcome would be not be unpredictable, nor would the lawsuit be other than routine. As Example (1) in the Official Commentary to USRAP § 3 (UPC $§ 2-903$ ) makes clear, the substitute gift to $B$ 's descendants would be reformed to make it vest in interest (not in possession) 90 years after the trust was created. See UNIF. STATUTORY R. AGAINST PERPETUTIES WITH 1990 AMENDMENTS $§ 3$ example 1 (1990). 
Before leaving the subject of perpetuities, I should add that the Dukeminier-French proposal to confer a special power on deceased remainder beneficiaries would increase, not decrease, the possibility of a perpetuity violation. Under both USRAP and the common-law Rule, the perpetuity period starts running on the exercise of a special power from the time that the original trust was created, not from the time that the power was exercised. ${ }^{181} \mathrm{~A}$ remainder beneficiary who would actually exercise the special power in further trust, say, for the life of the remainder beneficiary's children, would blunder into a perpetuity violation if one or more of his or her children were born after the original trust was created. ${ }^{182}$

\section{E. Wholesale Revision of Trust Forms?}

The Dukeminier article gives the impression that UPC section 2707 interferes with mainstream estate planning. It does not. Section 2707 only applies to poorly drafted trusts, the type of trust that so often becomes embroiled in litigation. Capable estate planners need not fear that UPC section 2-707 will interfere with their work product or that they will have to "revise their trust forms." 183 Since section $2-707$ only applies to poorly drafted trusts, the only practitioners who will have to revise their forms are those who ought to revise their forms, such as the practitioners who drafted the dispositions in Krooss, Bomberger, Lawson, Gustafson, Cox, Edwards, Peadro, and De Korwin, ${ }^{184}$ not to mention the outlier dispositions used by Dukeminier in Upending Remainders.

181. See UNIF. PROB. CODE § 2-902 (1993).

182. French, but not Dukeminier, acknowledges this point. French dismisses the problem by saying that "the Rule should cause little difficulty" in a jurisdiction that adopts the wait-and-see method of perpetuity reform (which is the reform that USRAP adopts). See French, supra note 142, at 823.

183. Dukeminier, supra note 4 , at 165 . Were he right about this, would not the Dukeminier-French proposal to confer a power of appointment on remainder beneficiaries predeceasing the distribution date also require a learning of new rules and revision of forms?

184. In re Krooss, 99 N.E.2d 222 (N.Y. 1951); In re Bomberger's Estate, 32 A.2d 729 (Pa. 1943); Lawson v. Lawson, 148 S.E.2d 546 (N.C. 1966); In re Gustafson, 547 N.E.2d 1152 (N.Y. 1989); Cox v. Forristall, 640 P.2d 878 (Kan. Ct. App. 1982); Edwards v. Bender, 25 So. 1010 (Ala. 1899); Peadro v. Peadro, 81 N.E.2d 192 (Ill. 1948); De Korwin v. First Natl., 179 F.2d 347 (7th Cir. 1949), cert. denied, 339 U.S. 982 (1950). 


\section{CONCLUSION}

Professor Dukeminier begins his article by saying that "[n]othing is more settled in the law of remainders than that an indefeasibly vested remainder is transmissible to the remainderman's heirs or devisees upon the remainderman's death." 185 He constructs his case for transmissible future interests on an indefeasibly vested remainder, in the form of an income-to- $A$-for-life, remainder-to- $B$ trust. This sort of simplistic trust is seldom seen in real-world practice. Focusing on indefeasibly vested remainders is calculated to give the false impression that transmissible future interests are deliberately created "to cede control of the remainder to the remainderman to permit the remainderman to deal with changes in his family circumstances during the life tenant's life." 186 To accept Dukeminier's thesis that section 2-707 is "revolutionary," based "purely on [the drafters'] own speculation," bereft of empirical evidence showing "that the common law has read people wrong for centuries," "retrogressive," and "a piece of feudalism redivivus," 187 one must disregard the Cox-Edwards line of authority, ${ }^{188}$ the literature reproving transmissible future interests, ${ }^{189}$ and the experience of those who drafted and approved section $2-707 .{ }^{190}$ One must also accept two propositions - (1) that practitioners deliberately create transmissible future interests in order to grant remainder beneficiaries the power to adjust to changed family circumstances and (2) that remainder beneficiaries and their attorneys recognize transmissible future interests when they see them, anticipate that the usually younger remainder beneficiary might predecease the usually older life tenant, and craft their wills to make specific disposition of their remainder interests should they die during the lifetime of the life tenant.

Usually, however, transmissible future interests are the product of mistake or lack of forethought on the part of the drafting attorney. ${ }^{191}$ Capable estate planners avoid transmissible future interests like the plague. The case law bears out the proposition that transmissible future interests are usually created by inadvertence. I find it hard to believe that the settlors in the actual cases discussed in this article realized that their dispositions created transmissible future interests. Certainly none of the actual remainder beneficiaries did what Dukeminier claims sec-

185. Dukeminier, supra note 4 , at 148 (emphasis added).

186. Id. at 150.

187. Id. at $148,150,166$.

188. See supra notes $35-48$ and accompanying text.

189. See supra notes $49-69$ and accompanying text.

190. See supra notes $135-40$ and accompanying text.

191. See supra notes 19-31 and accompanying text. 
tion 2-707 deprives him or her of the flexibility of doing - disposing of the remainder interest "to deal with changes in his family circumstances during the life tenant's life." Finally, I find it hard to believe that the actual settlors in the poorly drafted trusts discussed in this article would have been satisfied with the outcome when the transmissible remainder interest ended up in the hands of outsiders. Far easier to believe is that most settlors of these and other poorly drafted trusts would endorse the outcome under section 2-707. 